Portland State University

PDXScholar

$1-1-2013$

\title{
Black and Blue: Police-Community Relations in Portland's Albina District, 1964-1985
}

\author{
Leanne Claire Serbulo \\ Portland State University \\ Karen J. Gibson \\ Portland State University, gibsonk@pdx.edu
}

Follow this and additional works at: https://pdxscholar.library.pdx.edu/usp_fac

Part of the Social History Commons, United States History Commons, and the Urban Studies and Planning Commons

Let us know how access to this document benefits you.

\section{Citation Details}

Serbulo, L. and Gibson, K. (2013). Black and Blue: Police-Community Relations in Portland's Albina District, 1964-1985. Oregon Historical Quarterly, 114 (1).

This Article is brought to you for free and open access. It has been accepted for inclusion in Urban Studies and Planning Faculty Publications and Presentations by an authorized administrator of PDXScholar. Please contact us if we can make this document more accessible: pdxscholar@pdx.edu. 


\section{LEANNE C. SERBULO \& KAREN J. GIBSON}

\section{Black and Blue}

\section{Police-Community Relations in Portland's Albina District, 1964-1985}

It appears that there is sufficient evidence to believe that the Portland Police Department indulges in stop and frisk practices in Albina. They seem to feel that they have the right to stop and frisk someone because his skin is black and he is in the black part of town.

—Attorney commenting in City Club of Portland's Report on Law Enforcement, $1968^{1}$

DURING THE 1960s, institutionalized discrimination, unemployment, and police brutality fueled inter-racial tensions in cities across America, including Portland, Oregon. Riots became more frequent, often resulting in death and destruction. Pres. Lyndon Johnson's National Advisory Commission on Civil Disorders issued in early 1968 what became known as the "Kerner Report," which declared that the nation was "moving toward two societies, one black, one white - separate and unequal." ${ }^{2}$ Later that year, the City Club of Portland published a document titled Report on Problems of Racial Justice in Portland, its own version of the national study. The report documented evidence of racial discrimination in numerous institutions, including the police bureau. The section "Police Policies, Attitudes, and Practices" began with the following statement:

The Mayor and the Chief of Police have indicated that in their opinions the Kerner Report is not applicable to Portland. Satisfactory police-citizen relations are not likely to be achieved as a reality in Portland in the absence of a fundamental change in the philosophy of the officials who formulate policy for the police bureau.

The City Club report also discussed the findings of the Kerner Report, noting that it "cited deep hostility between police and ghetto communities as a primary cause of the disorders" in dozens of cities, while arguing that in a 


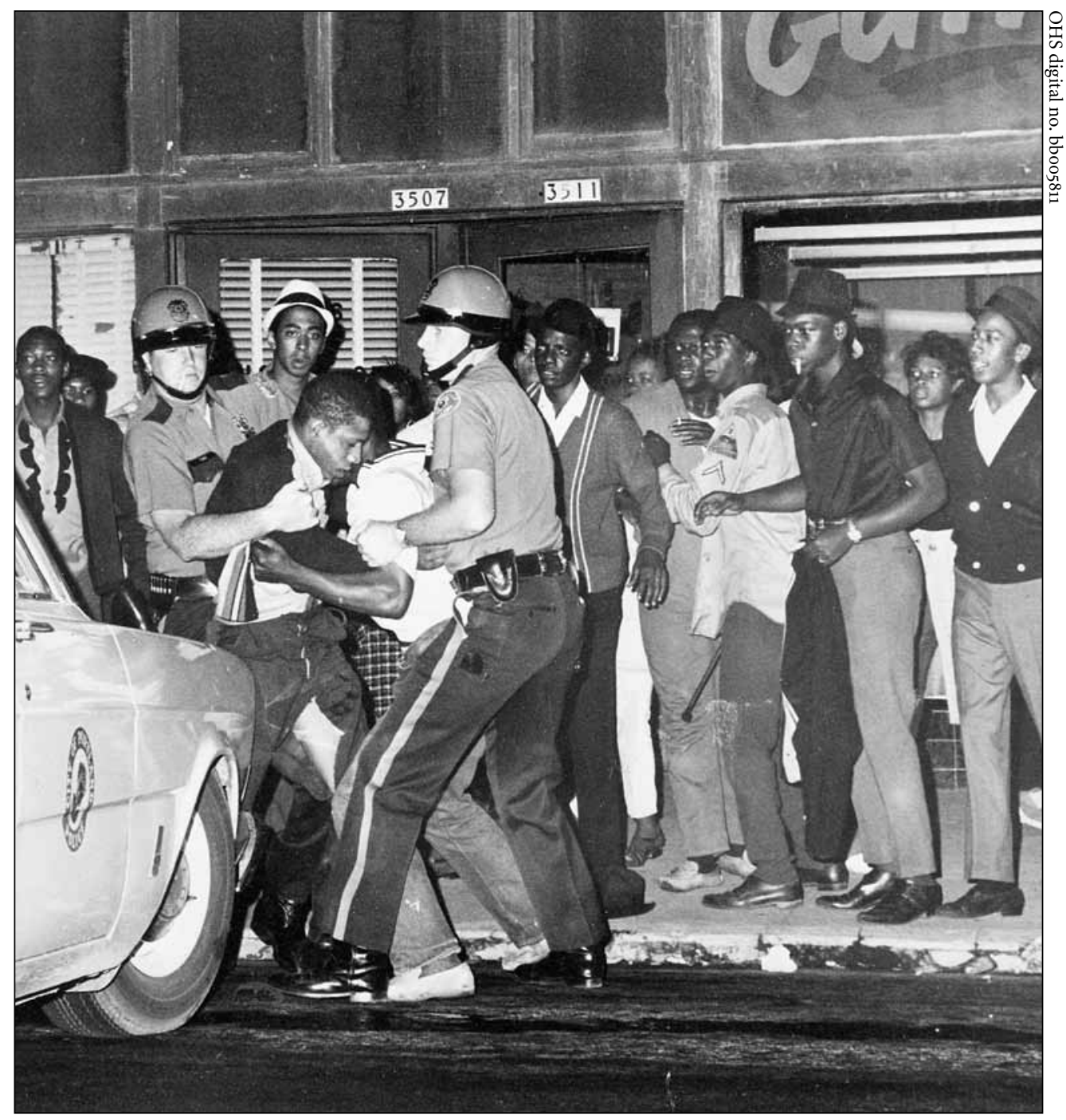

Portland police clash with young Albina residents on Union Avenue in 1969. By 1960, four-fifths of the city's black population lived in the Albina neighborhood - a result of racial segregation and isolation - while the vast majority of officers who policed the neighborhood were white.

"fundamental sense" it would be wrong to characterize the problem "solely as hostility to police." Police officers, it explained, represented not just law enforcement but also "much deeper problems" within the larger society: "The policeman in the ghetto is a symbol, finally, of a society from which many ghetto Negroes are increasingly alienated." 3 
In 1968, the City Club of Portland also issued a document titled Report on Law Enforcement in the City of Portland, which confirmed what many in Portland's African American community already knew. In the Albina neighborhood, citizen harassment and social control were higher Police Bureau priorities than public safety. At that time, African Americans comprised more than 60 percent of some Albina District neighborhoods, yet they made up just 1 percent of Portland's 720 police officers. ${ }^{4}$ Rev. Eugene Boyd, co-founder of the Albina Ministerial Alliance, recalled the difficulty of gaining police services during the early 1960s: "We knew that our part of the city had been designated as where all this stuff [crime, drugs, prostitution] should go on." According to Richard White's study of faith-based community organizing in Portland,

[Boyd] and a small contingency of pastors and neighbors met with a deputy police chief who referred to Albina as "the Tombstone territory," indicating that the "law of the streets" would have to prevail because the police would offer no additional help. When the same group met with Mayor Terry Schrunk, Boyd said the Mayor calmly asserted that because illicit drug use was relatively confined to black neighborhoods it was not really a large enough concern to warrant an additional police presence.

Boyd reasoned that the city's neglect of crime and public safety issues in Albina prevented black citizens from being "accepted by the whole community."'

Patterns of residential segregation and racial isolation led many residents in Albina and similar inner-city neighborhoods across the country to view their communities as internal colonies, dependent on outsiders for political and economic resources and subject to the authority of white-dominated institutions such as the school district, police, and welfare bureaucracy. After an uprising in the summer of 1967, youth worker Frank Fair spoke of a "new awareness" among Albina youth: "They come to realize that if Albina is going to be categorized as a colony, something separate and foreign from the city, they'll have to deal with their problems on those terms."

Historian Kevin Mumford discusses how the Kerner Commission's interviews with "local black militants" after the 1967 Newark uprising revealed "their deep resentment of the police and diminished faith in the government," which made them "more likely to speak of analogies with colonial military struggles" and to "identify with international struggles against domination." Historian Thomas Sugrue notes in his Sweet Land of Liberty that northern black urbanites had their consciousness raised by the colonial analogy and sought to gain control of their own communities through uprisings, organizing, and political activism during the late $1960{ }^{8}{ }^{8}$ The colonial framework challenged liberalism because it argued for the redistribution 
of power and institutional control, rather than assimilation and integration into existing institutions through practices such as school busing and affirmative action. Despite popular acceptance of the colonial understanding of race relations, it never attained acceptance in mainstream intellectual circles because of its association with the black power movement. ${ }^{9}$

In a 1975 article on race and crime, sociologist Robert Staples explained that according to the colonial model police acted as "agents to enforce the status quo." The police role in the black community was not to provide for public safety but to "protect the property of the colonizers who live outside those communities and to restrain any black person from breaking out of the colonial wards in the event of violence."10 The findings of the Kerner Commission, showing differential treatment of black communities (more tolerance of illegal activities and violence, police brutality, and less urgent responses to calls for help), therefore should come as no surprise. According to the colonial model, the lack of black representation in law enforcement and the prejudiced attitudes of white police were to be expected, because the police were agents of the colonizer, who used the rule of law to control the dependent ghetto colony.

Contemporary perceptions of the police are similar to Staples's argument that the police oversaw inhabitants of "colonial wards" in order to reinforce the status quo in race relations. Those perceptions also demonstrate that the colonial model retains some explanatory power for understanding today's police-community relations. ${ }^{.1}$ Despite the long-standing controversy over racial profiling and the use of force on black suspects, historian Marcy Sacks notes that there has been little "scholarly inquiry into the origins and implications of the uneasy relationship between urban black populations and overwhelmingly white police forces." ${ }^{12}$ While many historical studies discuss the role of police brutality in setting off riots throughout the twentieth century, few studies analyze in detail the relationship between the police and majority-black urban communities. ${ }^{13}$ Sacks shows that as the black population grew in Manhattan at the turn of the twentieth century, black people were "singled out as targets of enmity and suspicion" and "harassed and brutalized by police officers" who "preferred to subjugate and intimidate" rather than protect, allowing "vice and crime to flourish in black neighborhoods." ${ }^{14}$ This article adds to that work by chronicling the history of the black community's attempts to reform policing in Portland's Albina District and the subsequent fierce resistance the community encountered from rank-and-file officers, police commanders, and elected officials.

The story begins in the mid 1960s, when policing became a major civil rights issue in Portland, and ends in 1985 with the murder of black Portlander Lloyd "Tony" Stevenson at the hands of the police. In Portland, three 
issues have been the objects of police reform: reduction of police brutality, increased civilian oversight of the police, and increased black representation in law enforcement. During the long and persistent struggle, some progress was made. Nevertheless, by the mid 1980s, the relationship between the Portland police and the black community remained essentially unchanged, and racial equality continued to be an elusive goal in Portland. The urgency with which black Portlanders pushed for police reform throughout that time suggests that they viewed police as playing a critical role in upholding structural inequality. This story also suggests that local politicians were responsible for instituting any meaningful reform that would have reshaped the relationship between the police and the black community.

THE CITY CLUB'S racial justice report found, in Portland, the same problems that the Kerner Commission found "to exist in large cities in general": "discrimination or inadequacies" in areas such as police practices, employment, housing, education, health, municipal services, and consumer treatment. It concluded that the causes and effects of these problems were similar, and that the "differences" between Portland's problems and "those of Watts, Newark, or Detroit" (where uprisings also took place) were just a matter of "degree." ${ }^{15}$ Throughout northern cities, local governments permitted vice to prosper in black districts and had the areas patrolled by non-resident white police. Sugrue writes: "Perhaps the biggest problem facing northern police departments, especially in cities with large black populations, was the paucity of black police officers." That lack of representation, combined with police harassment, helped delegitimize law enforcement authority among blacks. In addition, the majority of northern blacks distrusted local government because of ongoing discriminatory policies having to do with housing, school segregation, and urban renewal. ${ }^{16}$ Stuart McElderry argues that, by 1940, the first phase of ghettoization was complete in Portland, with 60 percent of the city's roughly 1,900 African Americans living in the Williams Avenue district because of hostility from white residents, real estate industry discrimination, and local public housing policy.7 During the 1950s, Albina's white population declined by half as its black population doubled. By 1960, four-fifths of the city's 15,000 African Americans were crowded into a two-and-a-half-square-mile area in the Albina District, and four elementary schools (Boise, Eliot, Humboldt, and King) were more than 90 percent black. ${ }^{18}$

In Albina, as in other black districts, urban renewal projects (such as Lloyd Center, Memorial Coliseum, and Emanuel Hospital) and highways (99W, I-5, and 405) reconfigured the neighborhood, increasing segregation from the 1950 s through the 1970 os. ${ }^{19}$ By 1970 , among West Coast cities, the 


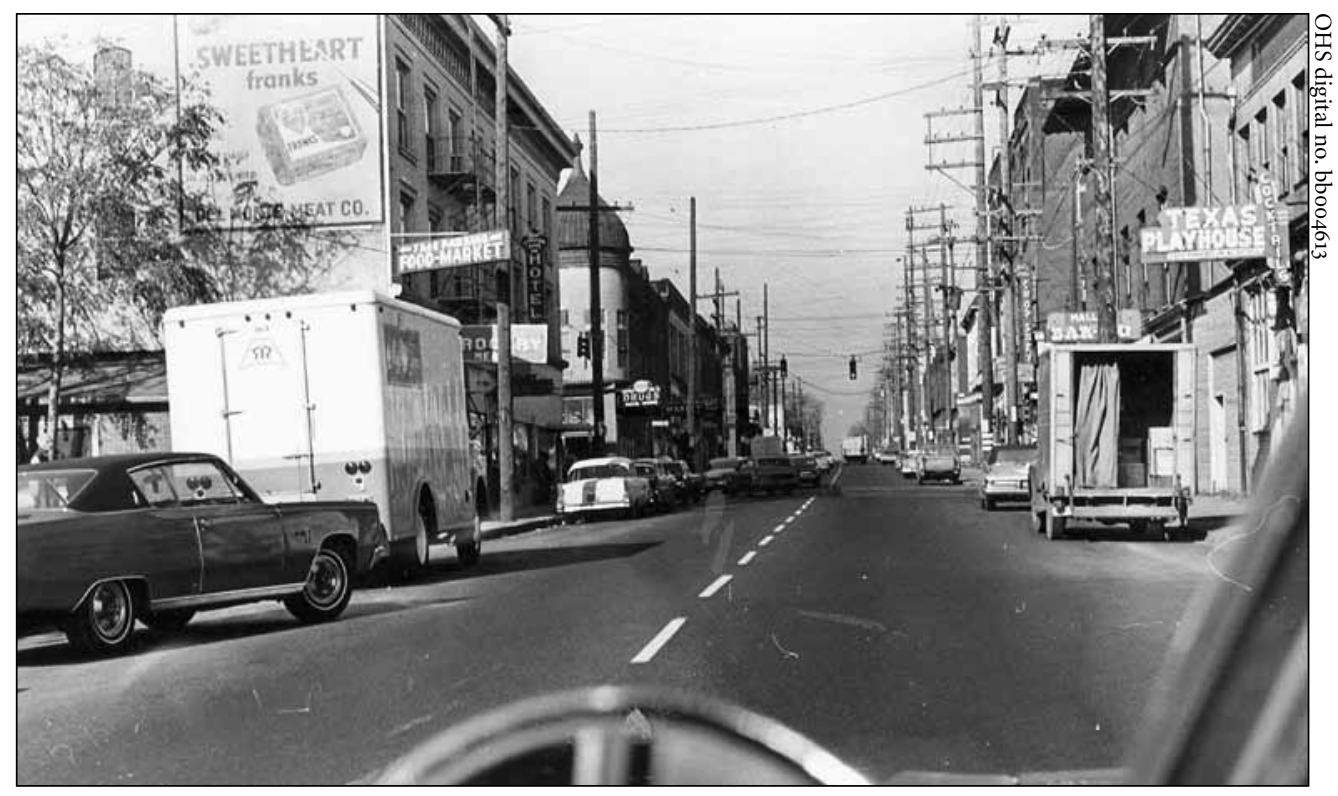

This photo looks north along N. Williams Avenue in 1967. Local newspapers referred to the area as crime-ridden, despite its thriving businesses and active neighborhood associations. A November 2, 1967, newspaper clipping attached to the photograph in the Oregon Historical Society's collection reads: "By day, even Portland's 'old town' streets look innocent enough; but at night, SW 1st to 3 rd and 'the avenue' $N$ Williams - come to life with activity city vice squad members do not consider healthy."

level of black-white residential segregation in Portland was second only to Los Angeles, as measured by the dissimilarity, or "evenness," index. ${ }^{20}$ Segregation meant that while the city was more than 90 percent white and the black population never exceeded 7 percent, there were neighborhoods in Albina that were more than two-thirds black. Those majority-black neighborhoods were patrolled by white police. The manifest power of residential segregation, urban renewal bulldozers, and police harassment and brutality prompted many black urbanites in Albina, and nationwide, to think of themselves as living in a colony subject to external rule. In response, activists worked to gain community control over local institutions, including the police.

During the early 1960s, 45 percent of all Portland arrestees were black, yet blacks made up less than 5 percent of the city's population. ${ }^{21}$ Racism within the criminal justice system had become part of the civil-rights discourse in Portland, and it appeared that policy changes might soon follow. In 1964, the death of Albina resident Cleotis Rhodes at the hands of the Portland police 
sparked a rewriting of the department's use-of-force policies. A grand jury cleared Officer Edwin Freeman, who had shot Rhodes after a traffic stop, of any criminal charges but found Freeman's actions "indefensible." ${ }^{22}$ The jury was bewildered by Freeman's decision to transport the injured man across town to Portland Sanitarium Hospital when Emanuel Hospital was just a few blocks away. That August, in response to Rhodes's death, newly sworn-in police chief Donald McNamara revised the bureau's Manual of Procedures on the use of weapons to read:

It is here emphasized that firearms are to be used only as a last resort when other means fail: a) to defend himself or another person from death or serious injury, b) to prevent the commission of a felony, c) to apprehend a fleeing felon or to prevent the escape of a convicted felon [emphasis added]. ${ }^{23}$

While Rhodes's death indicated that deep problems existed between the police and the black community, McNamara's response to the shooting seemed to signal a willingness to work on improving relations.

Most rank-and-file officers, however, were not advocates of racial equality. According to a 1966 survey of Portland police, 86 percent of officers believed that the civil rights movement was "moving too fast," and more than half believed racial equality was happening "much too fast." ${ }^{24}$ Portland police officers' attitudes toward civil rights mirrored those of their counterparts around the country, but the resistance to racial equality was comparatively pronounced in Portland. Nevertheless, the Portland Police Intelligence Division did not begin to closely monitor activists in the civil rights movement until the mid 1960s.

The Portland police, like departments in many other major urban areas, had a history of monitoring and harassing political activists that dated to the establishment of Red Squads in the 1920s. ${ }^{25}$ In the mid 1960s, rank-andfile officers considered spying on political organizations a legitimate police function. A 1966 survey of Portland police officers ranked "keeping track of subversives" as the eighth most important aspect of policing, above "traffic duties," "control of vice," and "helping little old ladies." ${ }^{26}$ The Intelligence Division not only collected information about political groups but also used that information to subvert activists. A lieutenant with the Portland Police Intelligence Division (also referred to in documents as the Intelligence Unit) compared the intelligence process to making bread: "You take some flour, water, yeast - massage it a little and come up with a product." ${ }^{27}$ Intelligence officers used information they gathered to spread rumors about their targets, foster dissension within and among activist organizations, and accuse targeted individuals of illegal subversive activity regardless of whether the information supported their charges. 
The respite from Intelligence Division monitoring that Portland's early civil rights organizations enjoyed ended once those organizations began to focus on issues of police brutality. In 1965, Melvin Spencer, Cleotis Rhodes's brother-in-law, came under police scrutiny after he attended a public hearing on police brutality organized by the City of Portland Intergroup Relations Committee. When police overheard committee member James Hill and his coworkers at the Upward Bound college readiness program making statements that were antagonistic to law enforcement, the Intelligence Division began keeping track of their movements and associations. The Intelligence Division even noted that one committee member was involved in an interracial relationship. Unlike other activist groups monitored by the Intelligence Unit, the civil rights and anti-poverty organizations had no ideological ties to left-wing or Communist groups. Most were engaged in government-sponsored War on Poverty efforts, but they also were vocal in their criticism of the Portland police. A group of anti-poverty and civil rights workers that the Intelligence Division called the "Activist Group" was working on a "project about police brutality, harassment, and intimidation." ${ }^{28}$ Many of those involved in War on Poverty efforts were young people who had experienced routine harassment by the police.

Civil rights and anti-poverty organizations' criticisms of the police reflected the growing frustration that many young Albina residents felt a frustration that erupted in the summer of 1967 in Irving Park. ${ }^{29}$ Young people threw rocks and bottles at the police, and the disturbance quickly moved to nearby Union Avenue, where fires were set, windows were broken, and a stereo store was looted. Unlike later riots in Albina, the Irving Park disturbance was not sparked by a specific incident. Young participants were frustrated by unresolved problems in their community and especially by the constant police presence. One rioter commented:

Where else but in Albina do cops hang around the streets and parks all day like plantation overseers? Just their presence antagonizes us. We feel like we are being watched all of the time..$^{30}$

After the Irving Park riot, police increased their surveillance of Albina neighborhood activists and meticulously recorded any confrontations they had with young black residents, often referring Albina youth to the Intelligence Division.

The Intelligence Unit scrutinized young activists who publicly criticized the police or were associated with other civil rights organizers already under surveillance. Through both direct observation and the use of informants, police kept track of activists' political activities, friends, and daily movements. As Intelligence gathered more information on activists, it cast a wider net, 


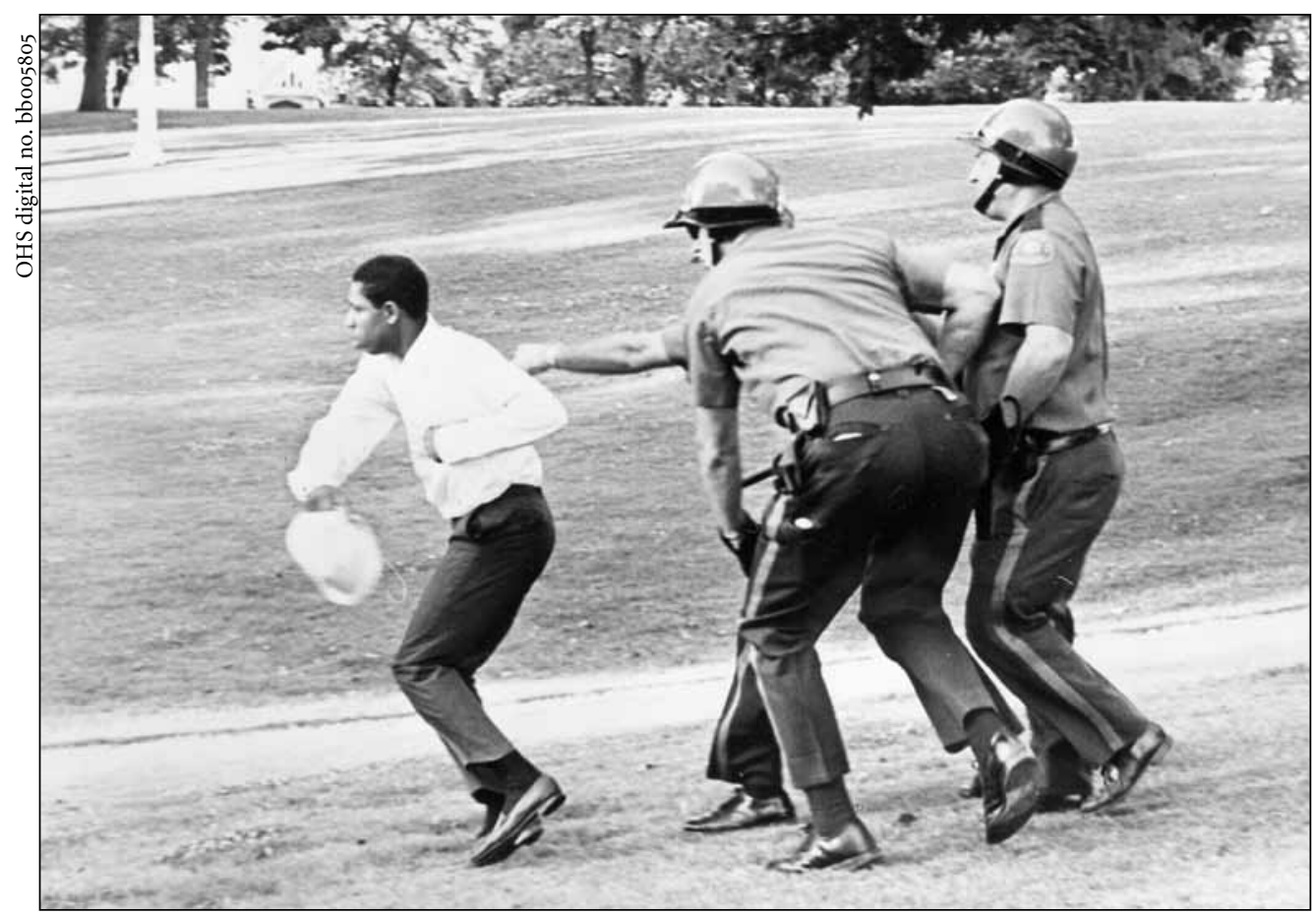

A man is chased by three Portland policemen during the 1967 Irving Park riot in Albina, an event that had begun as a peaceful rally by black activists.

entangling more Albina civil rights organizers into the investigation. Once an activist was caught up in an Intelligence inquiry, officers attempted to link him or her to various illegal activities until they found a charge that would stick; for example, the police arrested Colton Brown, an Upward Bound worker, on a charge of mail fraud for neglecting to fill orders for his company, Black Fashion Inc. ${ }^{31}$

By the late 1960s, the Intelligence Unit's monitoring of civil rights activists intensified, partly due to heightened federal efforts to monitor and disrupt the civil rights movement. In March 1968, FBI Director J. Edgar Hoover expanded his agency's domestic counter-intelligence program (COINTELPRO) to a number of states, including Oregon..$^{32}$ Hoover ordered each office to designate one FBI agent to direct COINTELPRO, aimed to disrupt and discredit the Black Nationalist movement, and to coordinate efforts with local police. The local FBI field office tried to persuade doctors to stop volunteering at the Black Panthers' health and dental clinics, attempted to inflame local Jewish leaders by accusing Black Nationalists of anti-Semitism, and falsely accused activists of being police informants. ${ }^{33}$ Portland police had been 
spying on political dissenters and actively disrupting political organizations for decades, but the federal COINTELPRO provided additional legitimacy and support for such activities.

By the early 1970s, however, many of the tactics that police had used to suppress civil rights activists and their work were being discredited. In 1971, an anonymous group called The Citizens Commission to Investigate the FBI broke into an agency field office near Philadelphia, stole COINTELPRO documents, and leaked them to the press. The publication of domestic spying documents prompted a major congressional investigation, headed by Sen. Frank Church of Idaho, which discovered that the FBI had been involved in political repression since World War I. The Church Committee's final report concluded that COINTELPRO was a "sophisticated vigilante operation aimed squarely at preventing the exercise of First Amendment rights of speech and association.. ${ }^{34}$ Hoover officially terminated the program in 1971. By the mid 1970s, the government was notifying citizens - including Portlanders - that they had been targets of COINTELPRO.

While the FBI was actively disrupting civil rights and black community organizations, other parts of the federal government were funding efforts to improve minority neighborhoods in response to the urban riots of the 1960s. Under the national Model Cities program, neighborhood residents took part in a comprehensive citizen-planning process to determine how best to allocate federal funds set aside to improve minority communities. Albina residents demanded that some funds be used to institute greater civilian oversight of the police. In response, McNamara established the Police Community Relations (PCR) Unit in $1968 .{ }^{35}$ The PCR Unit did not allow civilian review of police activities; its mission was to improve communication and relationships between the police and Albina residents. The unit was small - consisting of just ten police officers, ten Community Services lay officers, and a youth worker - and had no bearing on regular police units assigned to the Albina area. Still, the Portland Police Bureau treated the unit as an "unwanted relative." According to the Metropolitan Human Rights Commission, the police force did not want to see an improvement in community relations. Instead, "top echelon men want to keep it [the bureau] twenty-five years behind the times." ${ }^{36}$ Even the relatively minor goal of the PCR Unit - to open up communication between Albina residents and officers who patrolled their neighborhood - was not endorsed by police leadership. When community members began to use the PCR Unit as a vehicle of reform, some police turned against their fellow officers.

In 1971, Roscoe La Verne "R.L." Anderson, a community activist who had a long, acrimonious relationship with the Portland police, was elected to the Model Cities Law and Justice Committee, which worked closely with 


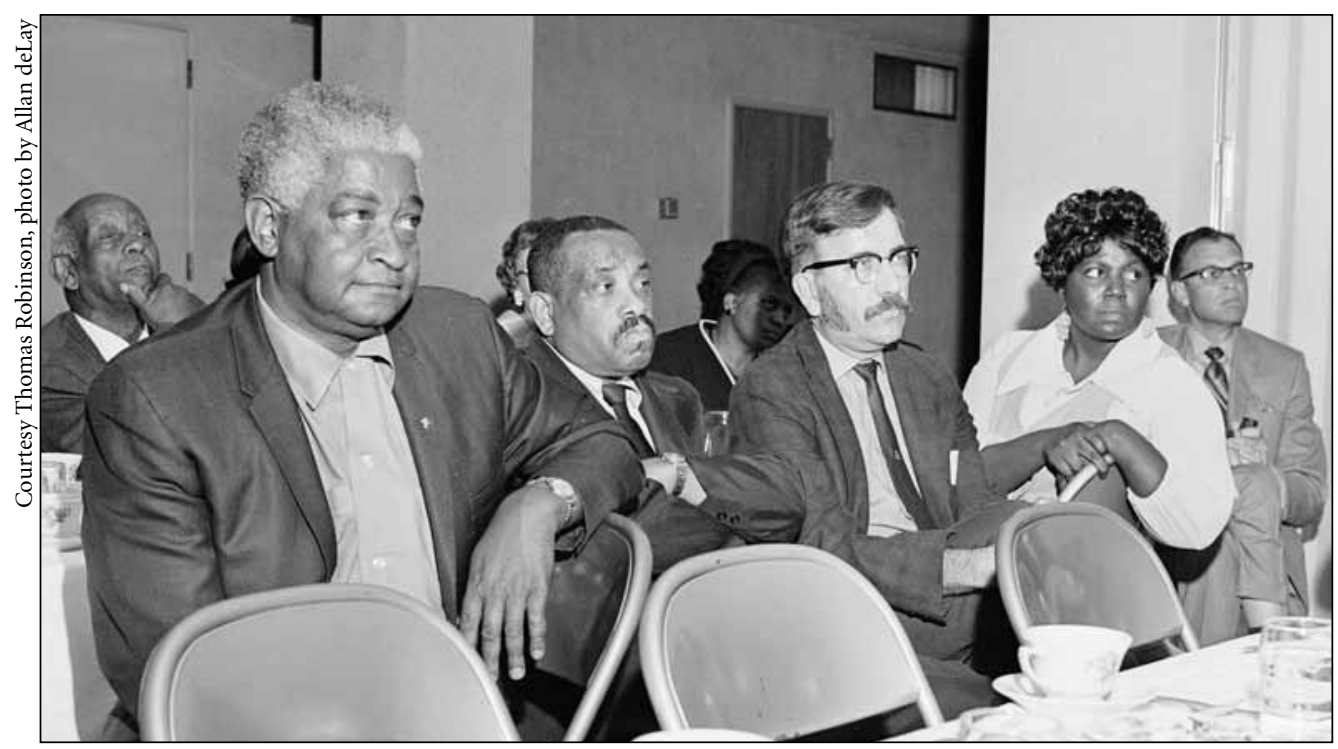

Albina District residents participated in the Model Cities Citizens Planning Board to help guide neighborhood improvements. Here, they meet in 1970 to discuss the expansion of Emanuel Hospital's campus. Between 1960 and 1980, roughly 1600 housing units were lost in lower Albina, mainly in the Lloyd District and Eliot neighborhoods, as a result of multiple urban renewal and freeway construction projects.

the PCR Unit. ${ }^{37}$ In his capacity as a Law and Justice Committee member, Anderson developed a good working relationship with the PCR Unit commander, Sgt. John Roe. Anderson's growing power within the Model Cities governing boards and Roe's tolerance of his presence angered many police superiors. In March 1971, Roe and another officer were transferred away from the PCR Unit, sparking protest by Model Cities Law and Justice Committee members. Anderson and other members threatened to go public with the names of officers assigned to Albina who had "racist attitudes" if Roe was not reinstated..$^{3}$ By that point, Anderson had been elected treasurer of the Portland Metropolitan Steering Committee (PMSC), the governing board of the Model Cities program. The Intelligence Unit immediately launched a campaign to destroy his credibility; and on April 1, 1971, Anderson was forced to resign his treasurer post. Shortly after Anderson resigned, Intelligence noted that Roe had "stopped and talked with" him, but the topic of their conversation was "unknown." Following that meeting, Intelligence officers began to note Roe's other activities as well, spying on him as he drank coffee and chatted with a former PCR colleague at a downtown Denny's restaurant. ${ }^{39}$ 
Ultimately, the PCR Unit was rendered ineffective by Roe's removal. Nine months after Roe's dismissal, the Model Cities Law and Justice Committee commissioned the director of Portland State University's Criminal Justice program, Dr. Lee P. Brown, to write a report on the PCR Unit. According to Brown, Roe was "open and honest about the shortcomings of the police," and since his dismissal, the only accomplishment of the program had been "its survival." Brown suggested that the biggest barrier to more positive police-community relations was that "police come from a totally different environment" and have a "stereotyped view of Model Cities residents." ${ }^{\circ}$ Norm Monroe, who worked as an administrative assistant in the PCR Unit, observed that police patrolled Albina using a "mechanized approach": they stayed in their cars and never walked the streets. Portland police assigned two people to each patrol car in Albina - other neighborhoods were assigned one. Monroe remarked that "it would be of value to treat the area like any other part of the Portland community."41

Albina residents wanted law enforcement to treat them like other Portlanders. When city government failed to listen to their pleas for equal justice, they took their demands to the courts. In the fall of 1969, Robert Probasco and thirteen other complainants filed a class action lawsuit on behalf of more than twenty thousand black Portlanders in U.S. District Court against Schrunk, the city council, McNamara, and thirty-eight Portland police officers. The suit petitioned the court to put a stop to the systematic harassment of blacks by the city and its police force. Police harassment, they claimed, resulted in black Portlanders living under "an atmosphere of fear and persecution" that had a "chilling effect upon the exercise of their federally protected rights." ${ }^{2}$ The case was settled in 1971 by a consent decree (which became known as the Probasco Decree) in which the city admitted no wrongdoing but agreed to cease specific activities. The court ordered Portland police to stop using "insulting, degrading or ethnically derogatory terms" toward blacks, to ban the use of shot-filled "sap gloves" and leaded batons, and to instruct all officers that they needed to have a search warrant before entering an Albina resident's home. ${ }^{43}$

The Probasco Decree sparked additional changes in police department policies. The Portland Police Bureau agreed to create an agency to hear citizens' complaints, to force officers to wear a badge and give their name if asked, to provide racial-sensitivity training to officers, and to create an affirmative action plan. ${ }^{44}$ To fulfill the requirements of the decree, the police bureau established a mechanism for dealing with citizen complaints. The resulting Internal Affairs Division was designed as an in-house alternative to a civilian review board, allowing the police force to "do its own cleaning." 45 Still, some rank-and-file officers were unhappy with the newly established 
process. They viewed Internal Affairs as a "secret police" and were worried that "police officers cannot please all the people all of the time, [and] those we arrest will come in here and tell lies." Those worries proved overblown. In its first year, 85 percent of complaints to the Internal Affairs Division were deemed "unfounded" or "exonerated," only 10 percent were sustained, and the remainder were dismissed for lack of evidence. ${ }^{46}$

Although Albina residents now had an avenue to seek redress in cases of police brutality and harassment, the Internal Affairs Division seemed to simply rubber-stamp police behavior. The interventionist tactics of the Intelligence Unit diminished throughout the 1970s, but the Internal Affairs Division failed to stop the routine harassment, excessive use of force, and pervasive racial discrimination that characterized policing in the Albina neighborhood. Rachel James, an Albina resident, wrote Mayor Neil Goldschmidt in 1974 about incidents of police brutality she had witnessed in the community:

For years black people in the Albina area have been bullied and victimized by our socalled law-men. ... It seems as if any time a police gets the urge to punch something, they snatch the first available black man they see, and use him to satisfy their savage egos. ${ }^{47}$

Often, police use of force turned deadly. Between October 1974 and March 1975, four black men were shot and killed by the Portland police. ${ }^{48}$ The fourth shooting sparked a loud outcry from the community, and the city agreed to hold an unprecedented public inquest hearing to determine if Officer Kenneth Sanford's shooting death of Rickie Charles Johnson was justified. Typically, police use-of-force cases were heard in closed grand jury sessions. The inquest jury determined that the shooting was justified by a vote of five to one; the dissenting vote belonged to the sole black jury member. ${ }^{49}$

In April 1975, Sidney Lezak, the U.S. Attorney for Oregon, asked the U.S. Department of Justice to launch an investigation into the Portland Police Bureau to determine if the deaths of four black Portlanders at the hands of the police indicated a broader pattern of civil rights violations..$^{50}$ Lezak initiated the investigation at the behest of the black community, and when no evidence of a pattern of civil rights violations emerged, he cautioned that the findings did not "necessarily imply approval of the police tactics used in each case." Lezak thanked the community for the "dignity with which they pressed their demands and their forbearance in awaiting results." ${ }^{\prime 1}$ Meanwhile, rank-and-file police officers were becoming increasingly threatened by the efforts to provide oversight of their actions. Lt. Tom Tebo, writing in the Portland Police Association's newspaper, compared the federal investigation and other oversight efforts to "ticks on a cow." ${ }^{2}$ If a cow had too many ticks, he explained, it would eventually die. 
In addition to police brutality and civilian oversight, a main area of contention between the police and the black community was bureau hiring practices. As part of the Probasco Decree, the police had agreed to adopt an affirmative action policy to increase the number of minority officers. Initially, the bureau adopted the city's plan for affirmative action; but in 1974, Bob Davis, an affirmative action specialist assigned to the police, quit the department because of its lack of commitment to minority hiring. 53 During his short tenure, Davis had been excluded from police bureau meetings about training, hiring, and recruitment. In 1975, the police adopted their own affirmative action plan, which set an ambitious goal of hiring seventy-five minority officers on the force by $1980 . .^{54}$

As part of the affirma-

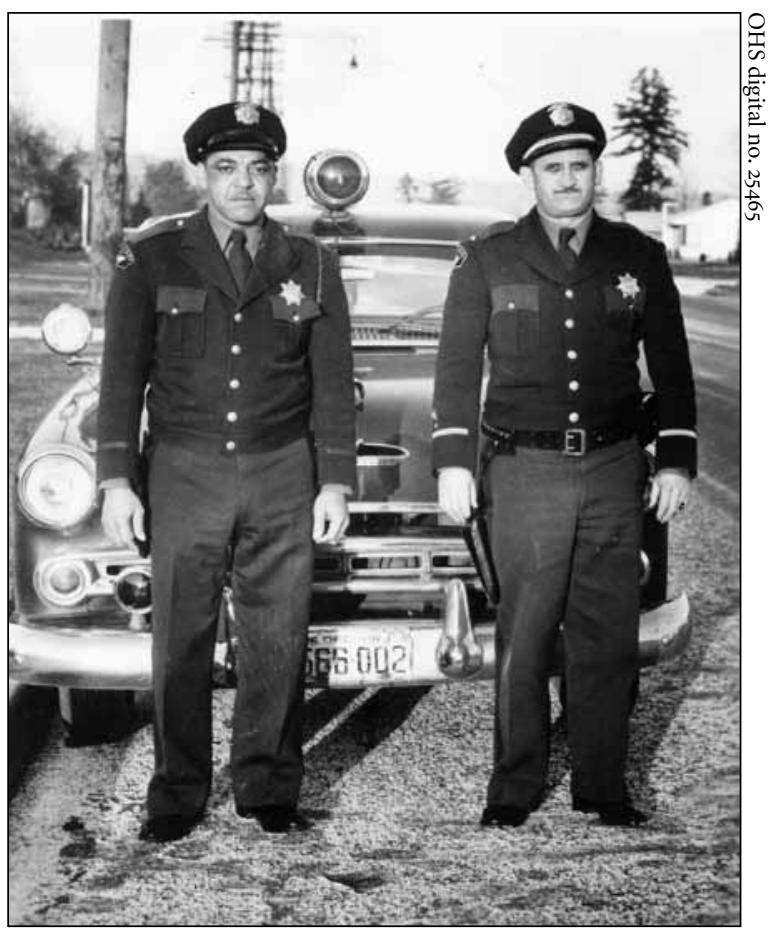

Black officers in the Portland Police Department were rare, and their small numbers were not representative of the population in Portland. Once in the force, they faced discrimination and harrassment. Bill Travis (left) was one of the first deputy sheriffs hired to patrol Vanport City during the 1940s. He is shown here in a Portland Police Department uniform in the mid 1950 s. tive action hiring push, the Portland Police Bureau sent recruiters to visit colleges in the South. ${ }^{55}$ Sgt. Norm Simmons, who went on one of those recruiting trips, lamented the fact that of the ten colleges they visited, seven were predominately white. In response to criticism about traveling to the South to recruit employees, bureau recruiter Marilyn Snowden observed that "for some reason minorities are not attracted to police work in their own communities."56 Dwight Ford, a recruiter for the bureau, linked black Portlanders' reluctance to work for the police bureau to "holdover attitudes from the turbulent 1960s." ${ }^{57}$ Attitudes from the $1960 \mathrm{~s}$ were also prevalent among police officers. Portland police officer Tony Newman recounted his experiences as one of the few blacks on the force: 
"I got the feeling after being on the Bureau a few months that I was being watched. Every black officer has heard the word 'nigger.' Every black officer has to listen to 'nigger' jokes and doesn't feel he can object." ${ }^{38}$

By 1980, minority recruitment efforts had been a dismal failure; the bureau was still 97 percent white and had only twelve black officers (1.7 percent).${ }^{59}$ One reason cited for the lack of minority recruitment was the implicit bias contained in the testing materials. ${ }^{60}$ There also was little support for affirmative action hiring among rank-and-file officers. When the bureau created a billboard campaign to attract minority recruits, one officer complained that it "smacks of racism." The billboard featured seven male and female police officers, four of whom were white, posing next to a slogan that stated the right color for a Portland police officer was "True Blue." Another officer objected because he thought it sent a message that "if you are not black or female there is no use to coming down to take the test." ${ }^{1}$

Despite efforts made during the 1970 s to diversify and provide effective oversight of the Portland Police Bureau, the relationship between the police and the black community remained essentially unchanged. By 1979, the Internal Affairs Division sustained only 7.3 percent of complaints. ${ }^{62}$ In the late 1970s, Dan Warren, a black Portland police officer, told a Willamette Week reporter about the "surprised looks" he got from black people he saw while patrolling. They would tell him: "I didn't know there was any of us on the police force." ${ }^{33}$ The lack of diversity in the police force and failures of the civilian oversight system contributed to a situation in which 60 percent of the people killed by the Portland police during the 1970 s were black, yet blacks comprised just 7 percent of the population. Oregon's prisons, furthermore, contained one of the "highest percentage of blacks as compared to the state population" within the United States. ${ }^{64}$

AFFIRMATIVE ACTION POLICIES and the establishment of an Internal Affairs process did not lead to significant changes in the relationship between the police and the black community in Portland, but the reforms did provoke a political backlash by rank-and-file police officers. ${ }^{65}$ The "Blue Power" movement was led by the Portland Police Association (PPA), the police officers' union. Officially recognized in 1942, the PPA was the first police union in the nation. ${ }^{66}$ During the late 1960 s, police across the country were becoming more politically active and vocal; many, for example, endorsed George Wallace's presidential campaign. After the city recognized the PPA as the bargaining representative for the Portland Police Department, the union became more involved in local politics. When collective bargaining talks with the city stalled in 1970, the PPA organized an informational picket of the ports along the Willamette River, effectively shutting down shipping in 
the city as unionized dockworkers refused to cross picket lines. The pickets forced the city to negotiate and empowered the police to become more involved in politics. In 1970, the PPA endorsed its first political candidate, Tom Walsh, who ran for Portland City Council and lost against Frank Ivancie, who had served as the police commissioner during the contract dispute and waterfront pickets. In 1976, newly elected PPA president Stan Peters stepped up the union's political involvement, arguing that joining the police force did not mean he had to "sign away his constitutional rights." ${ }^{7}$

In addition to endorsing political candidates, the PPA also initiated civil lawsuits against civilians. The union's "Blue Liberation" campaign turned the Internal Affairs process on its head by having the police sue people who had assaulted them during arrest. ${ }^{68}$ Between 1978 and 1982, the union won twelve lawsuits against civilians. ${ }^{69}$ Americans for Effective Law Enforcement recognized the "Blue Liberation" campaign at its 1982 conference and celebrated the PPA for being the "vanguard" of a new movement. In 1981, the PPA expanded its lawsuit campaign, suing the Oregonian for libel on behalf of Sgt. John McNabb after the paper printed an investigative article exposing his reputation as a racist police officer..$^{70}$

Within this context of a highly empowered police union, Albina community members founded a new civil rights organization called the Black United Front (BUF). In 1981, BUF filed a complaint with the United Nations (UN) Commission on Human Rights against the City of Portland and the State of Oregon for violating the human rights of black people within the criminal justice system. ${ }^{11}$ At that time, Oregon and Washington had the most disproportionate rate of imprisonment for blacks in the nation. Blacks comprised just 4 percent of Multnomah County's population but made up 22 percent of those arrested. ${ }^{2}$ At more than five times the proportion of the population, that was significantly higher than the national black arrest rate, which was three times the proportion of the population. In response to the complaint, Peters went to the press proclaiming in the papers and on the KATU News Town Hall television program that the police were not racist. Black people just committed more crimes per capita, he explained, using statistics about rape - historically, a racially charged crime - to support his claim. ${ }^{73}$ Members of BUF acknowledged that their chances of having the UN Human Rights Commission investigate their complaint were "slim," but they defended their application by arguing that chances for racial equality in Portland were "equally as slim," compelling them to pursue all avenues for equal justice. The commission reviewed the complaint at its summer meeting, but no action was taken. ${ }^{74}$

While the black community was pushing for significant changes to the structure and function of the criminal justice system in Portland, Commis- 
sioner Charles Jordan, who oversaw the Police Bureau, was implementing incremental reforms. Frustrated with the lack of results from current affirmative action policies, Jordan, the first black elected official in the City of Portland, proposed a two-tier civil service system to create more opportunities for minority candidates to advance through the police hiring process. In 1980, the PPA filed a lawsuit to stop the proposed civil service reforms, claiming they would "result in a decline in the quality of the police bureau."75 A judge ruled that the reforms were wrongly instituted by a board that lacked authority to do so, forcing the city to change its affirmative action plans. ${ }^{76}$ Jordan also appointed a Citizens' Task Force to review the Internal Affairs process and to recommend any necessary changes. When Jordan refused to appoint a representative of BUF to the Citizens' Task Force, BUF disapproved of his decision, claiming it was especially "disappointing" coming from a black politician. ${ }^{77}$ Tensions were high among the PPA, Jordan, and BUF, and they were about to become even more enflamed.

On the night of March 12, 1981, Officers Craig Ward and Jim Galloway dumped four dead opossums on the doorstep of the Burger Barn, a popular black-owned restaurant on Union Avenue. ${ }^{8}$ Witnesses to the incident saw four patrol cars pull up to the restaurant and claimed seven officers were involved in dumping the dead animals. Black community organizations responded with press conferences and marches denouncing the police

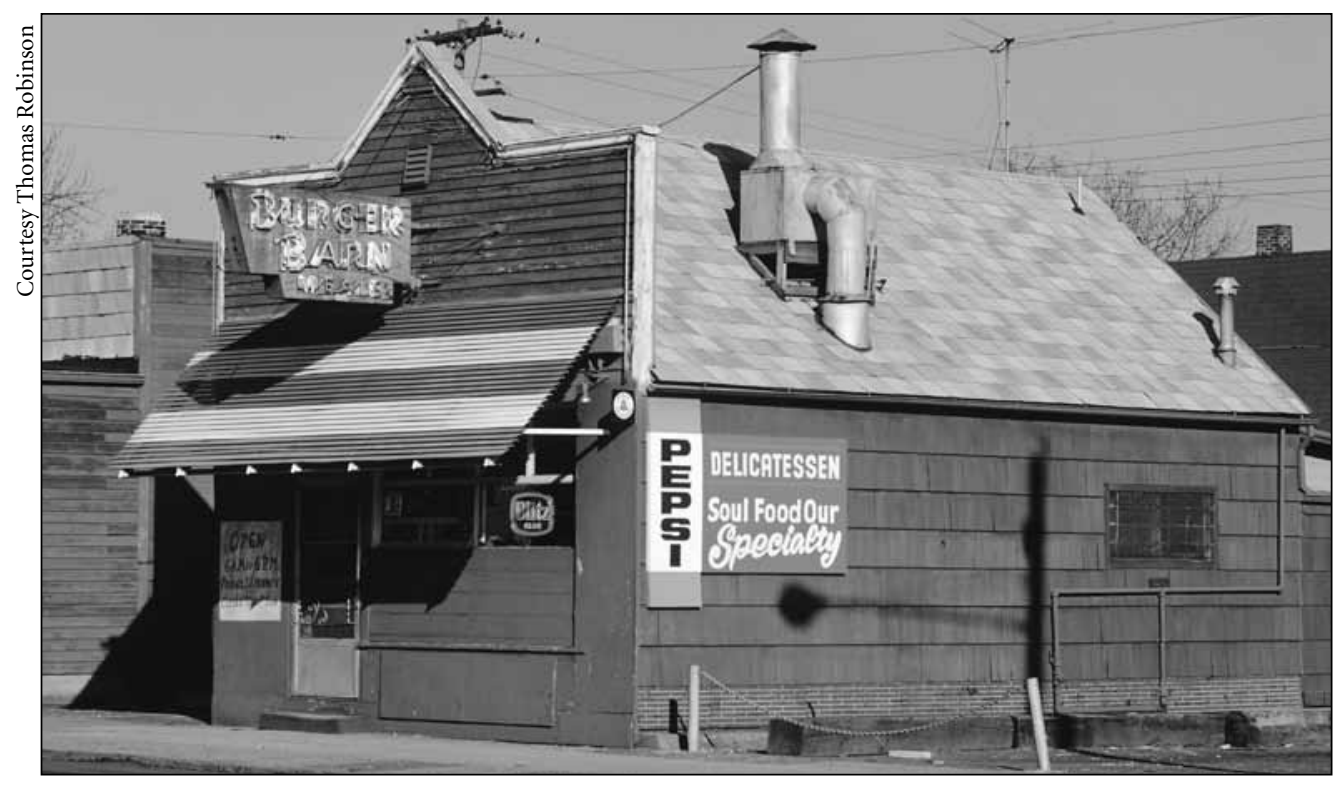

In 1981, policemen placed dead opossums on the doorstep of the Burger Barn, a black-owned restaurant on Union Avenue. 
actions as racially motivated harassment. Burger Barn owner George Powe believed it was part of a larger campaign of harassment intended to drive customers away from his business. "You would think the police would have better things to do," Powe remarked. Jordan and Police Chief Bruce Baker urged patience and calm while the Internal Affairs Division investigated the incident. BUF and other community organizations demanded the officers be fired and described the Internal Affairs investigation as being akin to "asking a hungry dog to guard a meat house." 79 On March 25, 1981, protestors marched, calling for the firing of all of the officers involved in the incident, the formation of a civilian review board, and better training and supervision of the police. Responding to intense public pressure, Jordan

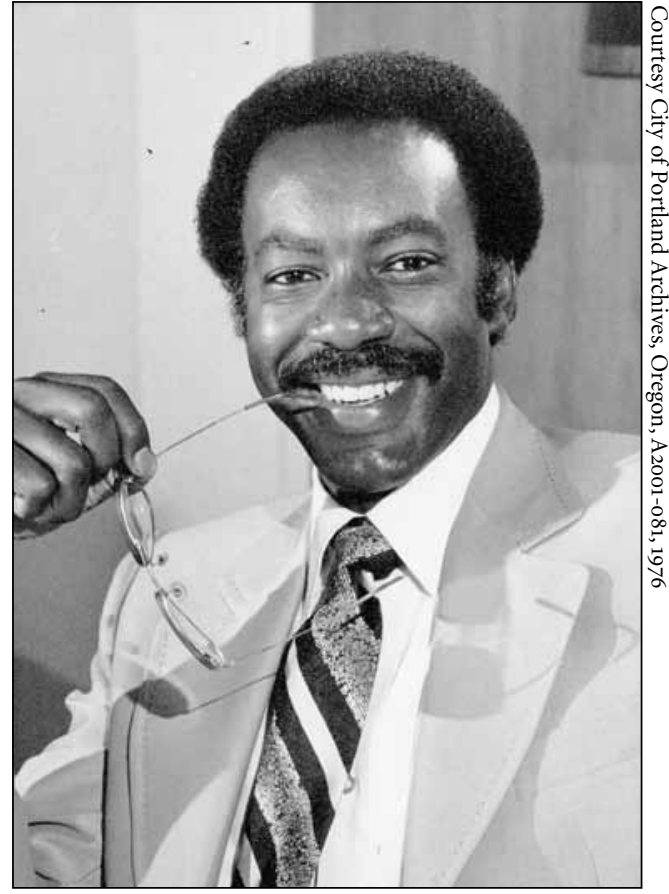

Charles Jordan was a Portland city commissioner for ten years starting in 1974. fired Ward and Galloway on March 26, 1981; none of the other officers received any reprimand. Ward and Galloway continued to claim that the incident was not racially motivated; they merely wanted to "relieve stress."

In response to the firing, Peters organized an emergency PPA meeting. The union took a no-confidence vote against Jordan and Baker, circulated a petition calling for Jordan's removal as police commissioner, and organized a rally to support Ward and Galloway. ${ }^{{ }^{11}}$ On April 3, 1981, one thousand police and supporters marched in a "Cops Have Rights Too" rally. The PPA contended that the firing of Ward and Galloway was politically motivated. The PPA's newsletter, The Rap Sheet, said that as the incident wore on it was clear the city was willing to "throw a pound of flesh to the wolves" and Jordan had decided to "throw the entire carcass to just satisfy their howling." ${ }^{82}$ After Ward and Galloway lost their jobs, the PPA hired them to work for the union with equivalent salaries and filed a grievance against the Police Bureau, protesting the firing of the two officers. ${ }^{83}$

Rumors swirled around City Hall that Mayor Frank Ivancie planned to remove the Police Bureau from Jordan's oversight. Jordan responded that 


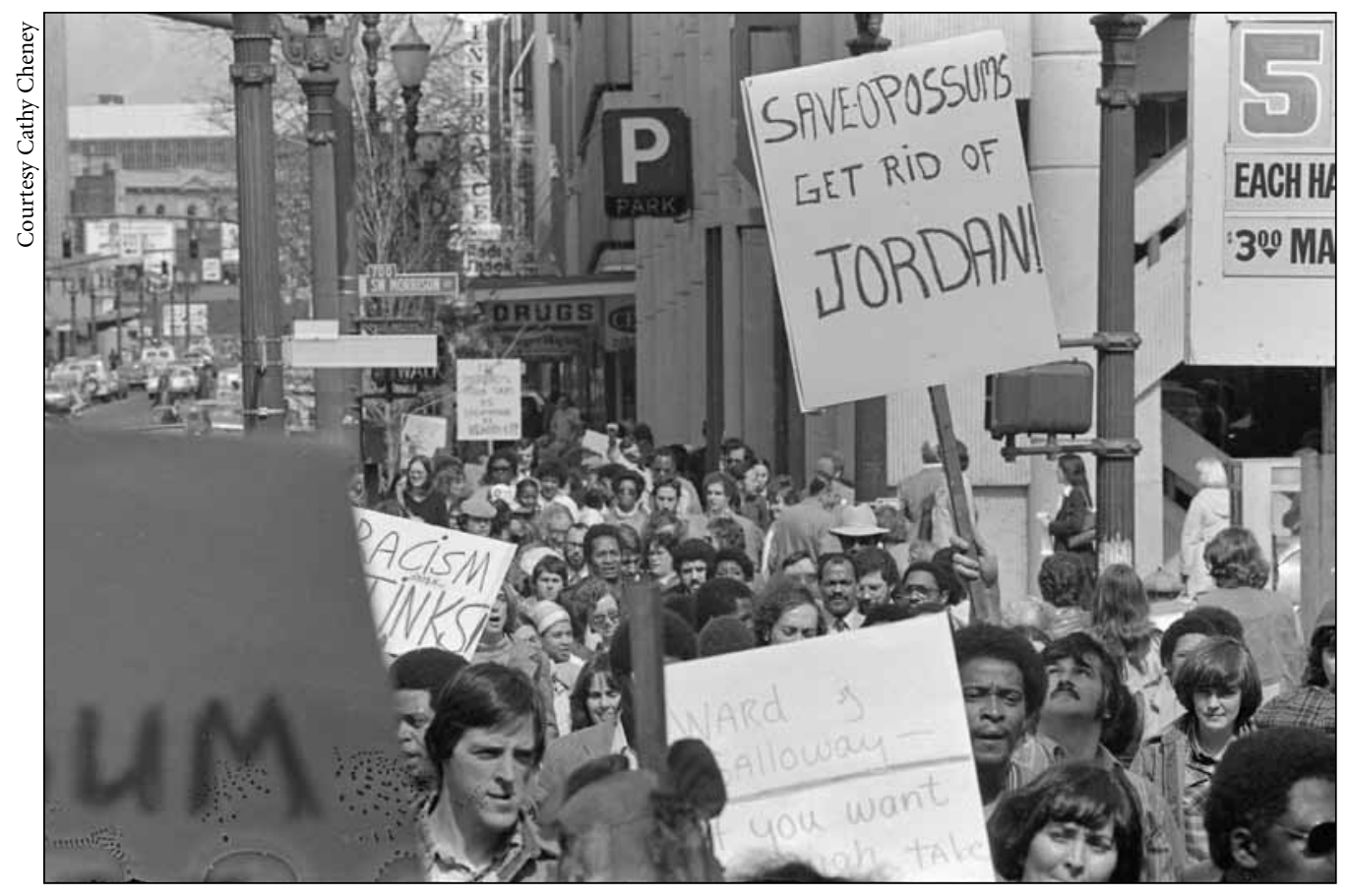

Portland residents protest in March 1981, demanding the firing of Craig Ward, Jim Galloway, and five other officers responsible for dumping dead opossums at the Burger Barn restaurant. They also demanded a civilian review board and better training and oversight of police.

if Ivancie took control of the police bureau, he would be "admitting that Stan Peters is running the city." ${ }^{84}$ On June 1, Ivancie relieved Jordan of his executive authority over the police bureau. Ivancie's first act as police commissioner was to appoint Lt. Ron Still to lead the bureau, replacing retiring Chief Baker. Still had led investigations against the Black Panthers breakfast program, was commander of the Special Investigation Division in the 1970 s when a major corruption scandal broke, and was a strong opponent of Jordan's affirmative action hiring policies. Black community leaders called Ivancie's choice for a new chief "frightening." ${ }^{85}$

Two months after Still took over, the grievance filed by the union on behalf of Ward and Galloway reached binding arbitration. The arbitrator, Gary L. Axon, ruled that Jordan had failed to follow proper procedures, and the two officers were reinstated with back pay. The black community was outraged and held marches and rallies in protest. Rev. C.T. Vivian, director of the National Anti-Klan Network, came to Portland to help organize an 
anti-Klan committee in response to fears that the arbitrator's ruling would embolden white supremacists in Oregon. ${ }^{86}$ Vivian saw the opossum incident as "one step away from putting the hood on" and believed the symbolic act represented a "Klan mentality" within the police force that threatened blacks. He went on to say that "it can be passed off as a joke by white people. It can't be passed off as a joke by black people." The Portland Police Intelligence Division responded to the criticism by opening a file on Vivian. ${ }^{87}$

Chief Still was an active opponent of any civilian oversight or reform, but public opinion grew increasingly critical of the police, driving a renewed effort to establish institutional checks on police behavior. In July 1981, the Citizens' Task Force on Internal Affairs, which had been organized by Jordan, released its final recommendations, including a call for the formation of a civilian oversight process. ${ }^{88}$ In May 1982, despite PPA accusations that Jordan was "still attempting to run the police bureau," the city council voted to establish a citizens' review committee. The day after passage of the review committee proposal, the PPA launched a petition drive to put the measure on the November ballot. ${ }^{89}$ The "Citizens for a Safe Portland Campaign" was the first referendum drive to reach the ballot in thirty years; the last referendum held in Portland had repealed the city council's public accommodation act, which eliminated racial segregation in commercial establishments in $1950 .{ }^{90}$ In November 1982, Portlanders voted by a narrow margin to accept the city council's citizen review process, and the Portland Police Internal Investigations Auditing Committee (PIIAC) was established. PIIAC could not investigate citizens' complaints or impose discipline on members of the Police Bureau; the committee merely provided oversight to the Internal Affairs process by issuing nonbinding recommendations. Still, the PPA remained staunchly opposed to PIIAC and encouraged officers not to cooperate. ${ }^{91}$ By 1987 , only two of PIIAC's twenty-eight recommendations had been fully followed. Committee vice chairwoman Jean Vessup said: "It's frustrating not being taken seriously."92

In 1985, Bud Clark began his mayoral term determined to improve the image of the Portland Police Bureau. He made leadership changes, replacing Still with the first female chief, Penny Harrington, but the leadership change did not result in any serious challenge to policing on the ground..$^{93}$ On April 20, 1985, police killed Lloyd “Tony" Stevenson, an African American off-duty security guard, in front of a convenience store near his home in Northeast Portland. Stevenson had helped calm a crowd during an altercation between the store owner and a suspected thief, but when police arrived, Stevenson, the only black man in the crowd, was wrestled to the ground by three officers and choked to death after Officer Gary Barbour used a "sleeper hold" on him. ${ }^{94}$ 


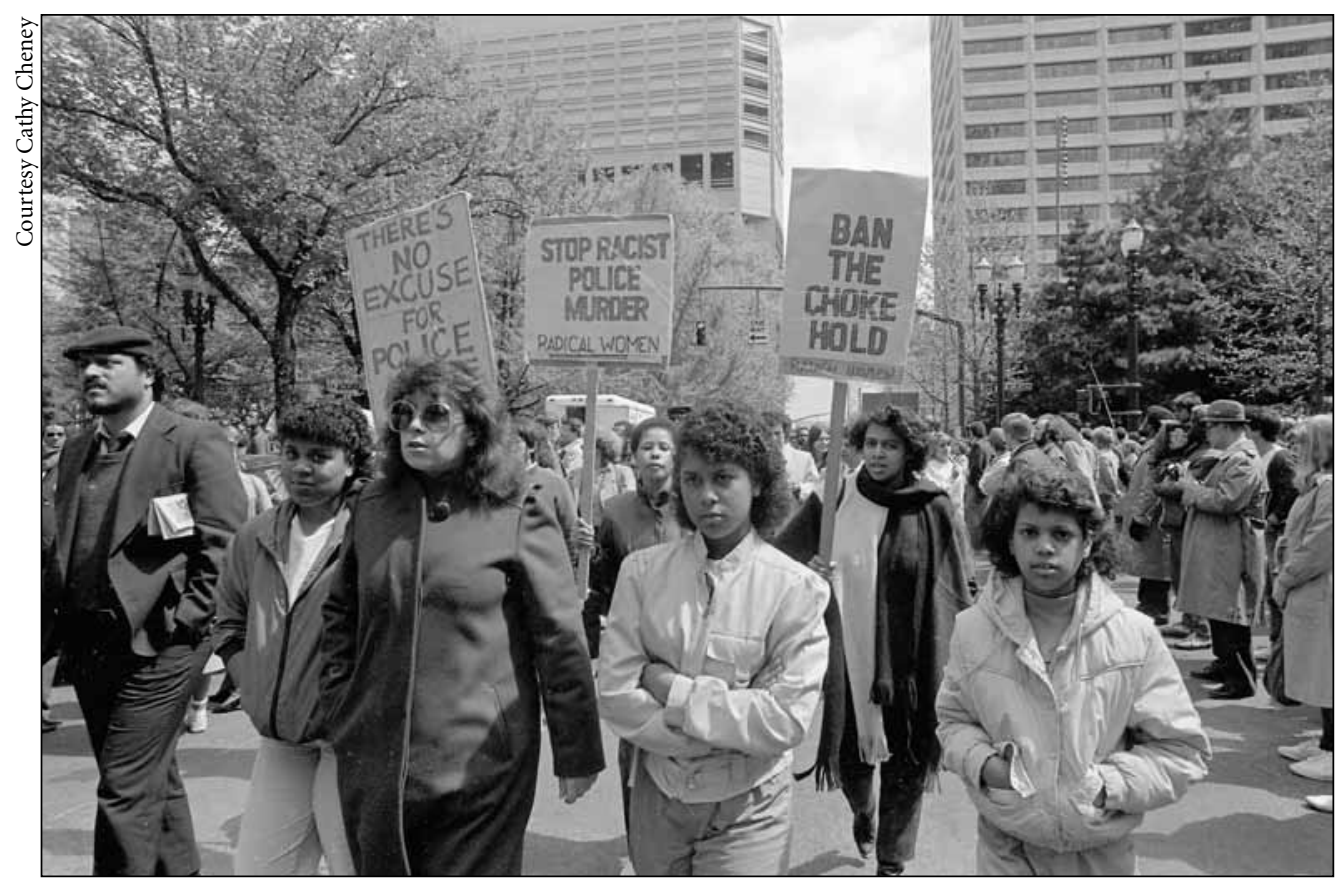

Portlanders protest the killing of Lloyd "Tony" Stevenson by Portland police in 1985.

In response, Harrington temporarily banned the use of the carotid artery "sleeper hold." After the ban was announced, Officers Richard Montee and Paul Wickersham printed 100 T-shirts that pictured a smoking gun and read: "Don't Choke 'Em. Smoke 'Em." They began selling the shirts on the day of Stevenson's funeral. ${ }^{95}$ Harrington fired the officers, and the PPA leapt to their defense, immediately filing a wrongful termination grievance. The Rap Sheet claimed the timing of the T-shirt sale was unfortunate because "only twelve people had a chance to purchase them," and insisted that the T-shirts were not insensitive, but rather reflected the "black humor that police use so they can live with themselves after picking up dead children." Much of the police force agreed. Three-quarters of officers believed the T-shirts were a "harmless prank that was blown out of proportion by the media"; and while 80 percent thought the T-shirts were bad for morale, 95 percent believed the firings of Montee and Wickersham were harmful to police morale. ${ }^{96}$ On October 23, 1985, arbitrator Paul Hanlon found that the city had wrongfully terminated Montee and Wickersham. ${ }^{97}$ They were immediately reinstated and their discipline reduced to six months lost pay. A few days later, the two officers filed a civil suit against the city, claiming their First Amendment rights had been violated. The case was dismissed..$^{98}$ 


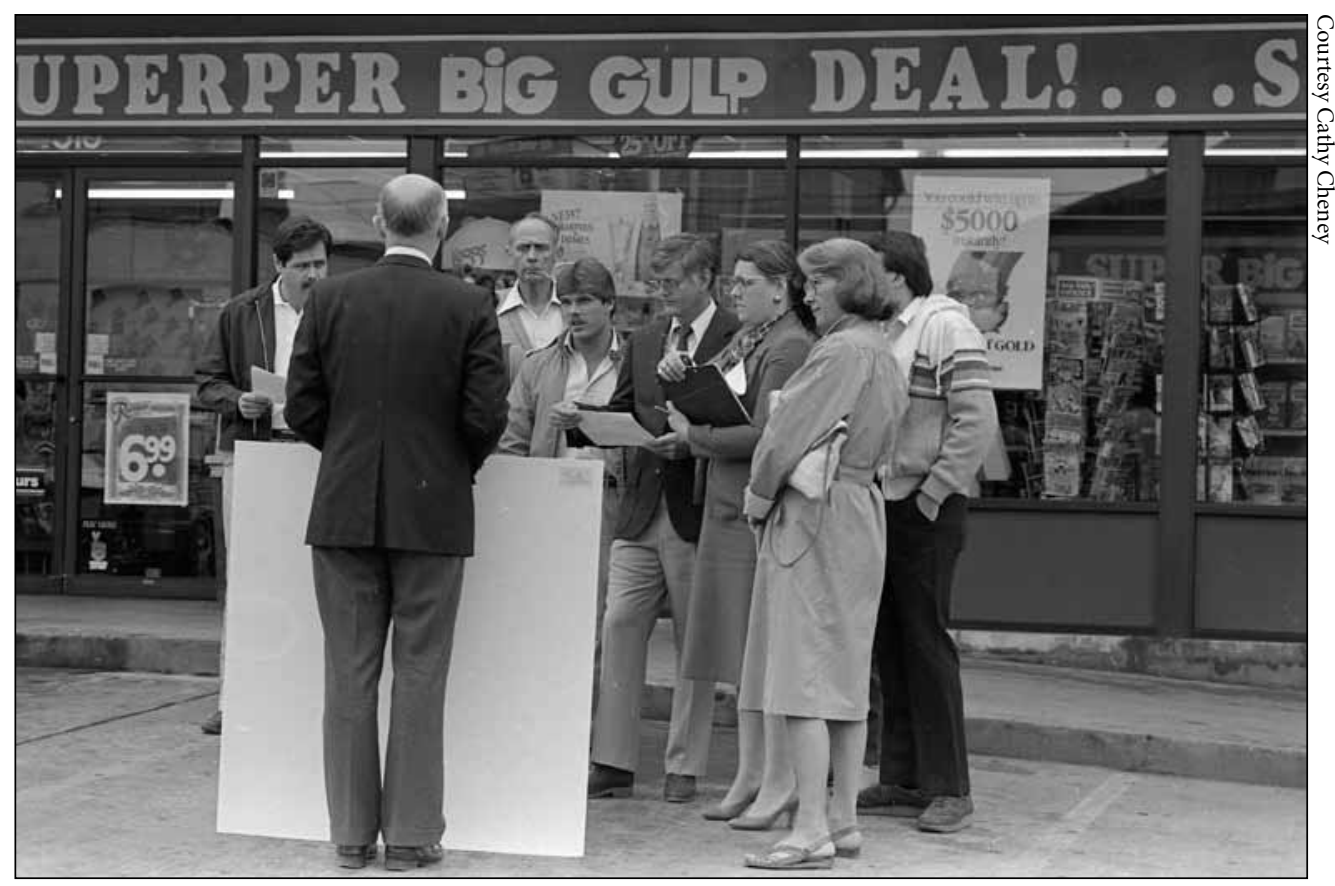

Inquest hearing jurors visit the convenience store on NE Weidler Street, where Stevenson was killed in 1985.

Barbour, who had used the "sleeper hold" on Stevenson, was never disciplined for his actions. For the first time since Rickie Charles Johnson's death in 1975, the city held a public inquest to look into the circumstances of a police-related death. The county district attorney questioned thirty-eight witnesses in a packed courtroom. The inquest jury found that Stevenson's death by choke hold - and the failure of officers to apply cardiopulmonary resuscitation - was homicide. Community leader Ron Herndon saw the all-white jury's verdict as a "very encouraging sign," but the inquest findings could not be used in any civil or criminal proceedings. ${ }^{99}$ Just weeks after the inquest, a grand jury decided not to bring charges against the officers. Stevenson's family, which included a wife and five children, would later be awarded $\$ 600,000$ by the City of Portland in an out-of-court settlement of a wrongful death lawsuit.

In 1964, the grand jury in the Cleotis Rhodes case was troubled by the fact that the police shot a man accused of a traffic violation and failed to provide adequate and timely medical attention that could have saved his life. Twenty-one years later, the inquest jury in the Stevenson case expressed similar concerns. Both cases sparked use-of-force policy changes, but those rules did not stop deaths from occurring in Albina at the hands of the Portland police. 
THE POLICY CHANGES were largely ineffectual because the problems between the police and Portland's black community were symptomatic of a much larger social issue - race relations in the city as a whole. At its roots, the city's relationship with its black community was fraught with enmity. Blacks had never been welcome in Oregon, and although the civil rights movement opened up unprecedented opportunities for African Americans between 1964 and 1985, the city remained heavily segregated. As late as 1986, Portland as a whole was 86 percent white; and of the city's entire black population, 80 percent lived in the inner northeast area. ${ }^{100}$

Although blacks were the majority population within the Albina community, they had little control over neighborhood conditions or institutions. In the late 1960 s, only 89 out of 1,978 businesses in the area were black-owned. ${ }^{101}$ Between 1965 and 1970, 60 of the 200 businesses along the main stretch of NE Union Avenue closed, leaving 35 vacant storefronts in a ten-block zone. ${ }^{102}$ As white business owners fled Albina during the 1960s and 1970s, the storefronts remained vacant, in part because Portland-area banks refused to issue business loans in redlined black neighborhoods. (Redlining is a term used to describe the process of denying loans to specific neighborhoods, primarily based on the community's social characteristics.) Aspiring black entrepreneurs were shut out of their own communities. City-wide, black home-ownership, employment, and high school graduation rates all lagged behind those of whites. The only statistics where blacks surpassed whites were arrest and incarceration rates. As dean of the University of Oregon law school Dr. Derrick Bell observed in the mid 1980s:

You might see few blacks on the streets of Portland, and virtually none outside the city. But the cellblocks of the state prison contains the highest percentage of blacks as compared to the state population of any state in the nation save our sister state, Washington. ${ }^{103}$

At the same time, Portland had gained a national reputation as one of the most livable cities, yet as Herndon noted, "that livability is not there for blacks, instead we get prison, unemployment, bad housing, and Klan-type harassment against a black family living in a Portland suburb."104

The lack of community ownership and control was glaringly reflected in the way the neighborhood was policed. In a report for the Governor's Commission on Black Affairs titled "Police in the 1980s," Charles Jordan noted that as long as the police force remained predominantly white, blacks would assume it defended white interests. Writer James Baldwin made a similar observation in 1960, using language reminiscent of the colonial model:

The only way to police a ghetto is to be oppressive.... Their presence is an insult and it would be, even if they spent their entire day feeding gumdrops to the children. They represent the force of the white world and that world's criminal profit and ease, to keep 


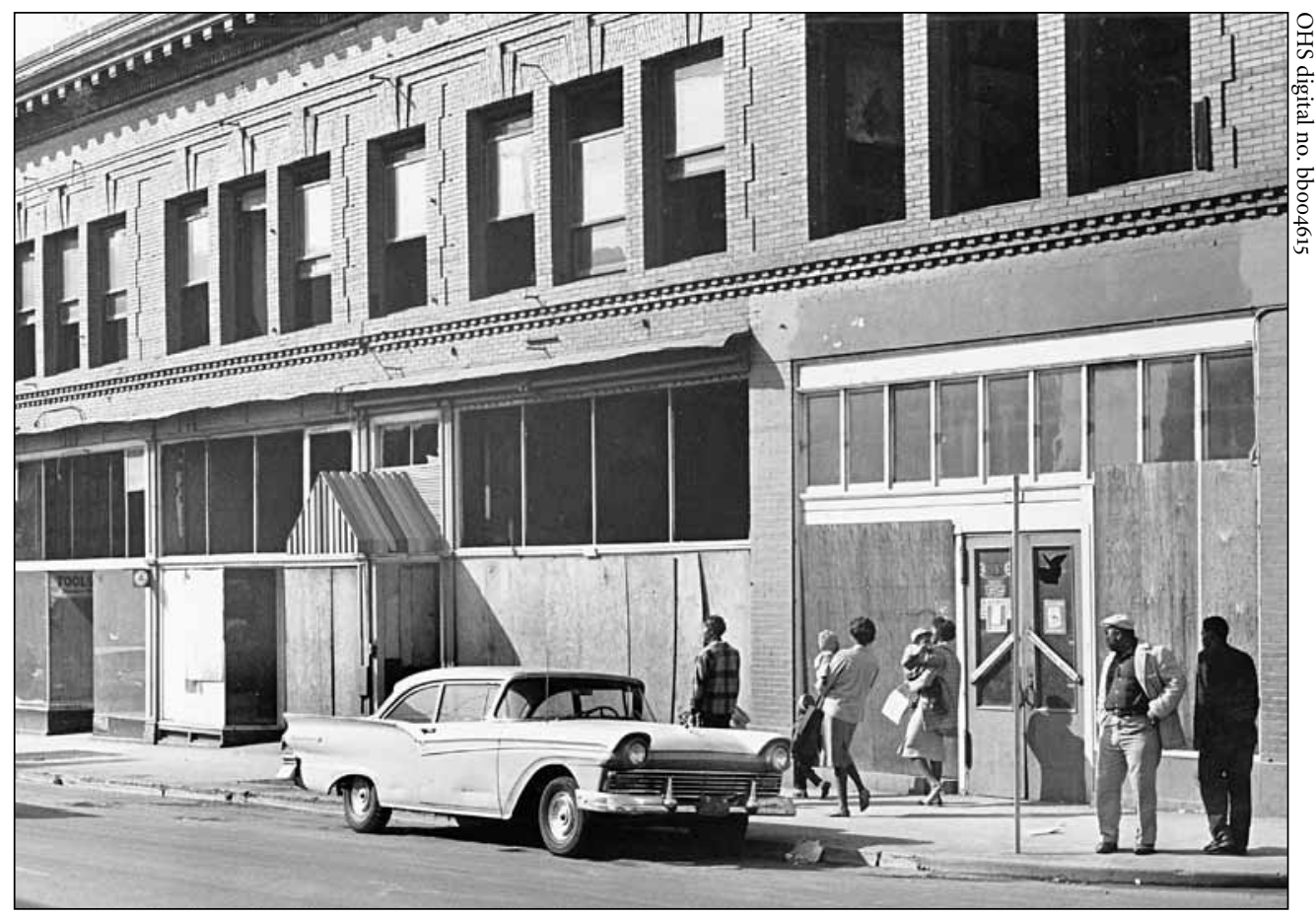

Boarded-up storefronts in the Albina neighborhood, shown here in this 1968 photograph, are signs of disinvestment in Portland's African American community.

the black man corralled up here, in its place. The badge, the gun and the holster, and the swinging club make vivid what will happen should his rebellion become overt.... He moves through Harlem, therefore, like an occupying soldier in a bitterly hostile country; which is precisely what, and where he is, and is the reason he walks in twos and threes. ${ }^{105}$

THE COLONIAL METAPHOR applied to policing in black communities during the 1960 s continued to be apt, despite any assumptions that the relationship between the police and African American communities had dramatically improved. When Bud Clark ran for mayor in the mid 1980s, for example, he was surprised to learn that "people were suspicious of the police. They saw them as an occupying army." ${ }^{106}$ The three main demands the black community had pushed for throughout the 1960s, 1970s, and 1980s in Portland - a reduction of police brutality, civilian oversight, and increased representation in police ranks — remained largely unrealized.

The relationship between the Portland police and the Albina community remained contentious throughout those decades because every organized attempt to reform the police was met with swift and hostile resistance. The 
PPA, especially under the leadership of Stan Peters, took over the retaliatory role the Intelligence Unit had played during the 1960s. While it is well within a labor union's purview to defend its members against administrative overreach and to provide representation to workers accused of misdeeds, the PPA went far above its stated mission to advocate for workplace rights and instead became a quasi-police force, accountable to no one, that flexed its muscle any time politicians or activists criticized or attempted to reform the police. Jordan once reminded rank-and-file officers that police are not like other public employees, because they have significantly more power than most public servants. ${ }^{107}$ The combination of the PPA's tenacious and vitriolic responses to any efforts to institute oversight of officers' actions and the power that police have compared to other civil servants led to a situation where many believed that, at times, the police union was actually running the city. ${ }^{108}$

Despite that perception, the police union does not run the city. It does not design and implement bureau policy. That responsibility lies with the police commissioner, mayor, and the city council. During this time period, however, every mayor, from Schrunk to Clark, failed to confront the police head-on. Even the most active reformers, such as Goldschmidt and Jordan, backed down when the police union dug in its heels. Most politicians ignored issues of racial injustice within the police department and responded only when the black community organized such strong resistance that they were forced to get involved.

Given the lack of support from elected officials and the outright hostility from rank-and-file police officers, it is no wonder that Portland's black community sought assistance from courts, the federal government, and even the United Nations. Their appeals to federal authorities to realize incremental reform was often more successful than their appeals to local politicians. The Probasco Decree, for example, laid the groundwork for many of the reforms that took place in the 1970s. Still, those external appeals fell far short of ensuring equal justice for black citizens in Portland.

SINCE 1985, the Portland Police Bureau has adopted community policing and hired its first black police chief, but deep-rooted problems remain. In 2012, a federal Department of Justice investigation found that the Portland police systematically have violated the civil rights of mentally ill residents. In a negotiated settlement with the U.S. Department of Justice, the police have agreed to modify use-of-force protocol and to establish a Community Oversight Advisory Board to monitor the implementation of the settlement. An interracial coalition of organizations demanded the federal investigation in response to the deaths of a number of Portland citizens at the hands of the 
police, including that of Aaron Campbell, a grief-stricken, young black man who police shot in the back after they were called to check on his welfare by concerned relatives. Ron Frashour, the officer who killed Aaron Campbell, was fired for failing to follow police use-of-force protocol. In keeping with precedents, Frashour was reinstated with back pay after the union pushed the case to arbitration. At the time of this writing, Mayor Sam Adams is challenging the legality of the arbitrator's ruling. ${ }^{109}$

While Adams's principled stance is encouraging, the circumstances of Campbell's death and the events that followed it remain troubling. Police initially told Campbell's family that he had committed suicide, and after family members filed a lawsuit, they began to experience police harassment. In a move reminiscent of Intelligence Division actions in the 196os, the police attempted to file charges against Campbell's uncle based on an unnamed informant's testimony that the uncle offered a bounty to anyone who would shoot and kill Frashour. The district attorney's office declined to file charges. According to Campbell's mother, Marva Davis, "it is a common perception in the Portland black community that the police will retaliate against anyone who challenges their authority."110 Her statement indicates that even now, little has changed. In addition to Campbell, black Portlanders Byron Hammick, Kendra James, Willie Thomas Grigsby, James Jahar Perez, Vernon Allen, and Keaton Otis were all killed in confrontations with the Portland police over the past decade. ${ }^{111}$ The civilian oversight function remains weak and ineffectual, and the police force is almost 90 percent white, with African American officers just 3.4 percent of the force, despite comprising 6.4 percent of the overall population and 25 percent of Albina District neighborhoods. ${ }^{112}$

The African American community in Portland - now more spatially dispersed, partially due to gentrification - may continue to suffer from police brutality. According to Dr. Leroy Haynes, chair of the Coalition for Justice and Police Reform, the main question is whether the city council "has enough courage and fortitude to exercise their authority" over law enforcement in the city. ${ }^{113}$

The colonial model is useful for understanding the historical continuities in police-community relations in Portland's Albina District and in black urban communities nationwide. Black thinkers and activists of the 1960 s explained police behavior as part of the colonization process that ghettoized black citizens, enforced their political and economic dependency, and thus led to the underdevelopment of black communities. Black citizens saw police officers as representatives of a state that had delegated "the legitimate use of violence to police authority" in the interest of black subordination. ${ }^{114}$ The problem was not just a matter of individually prejudiced cops, but rather 


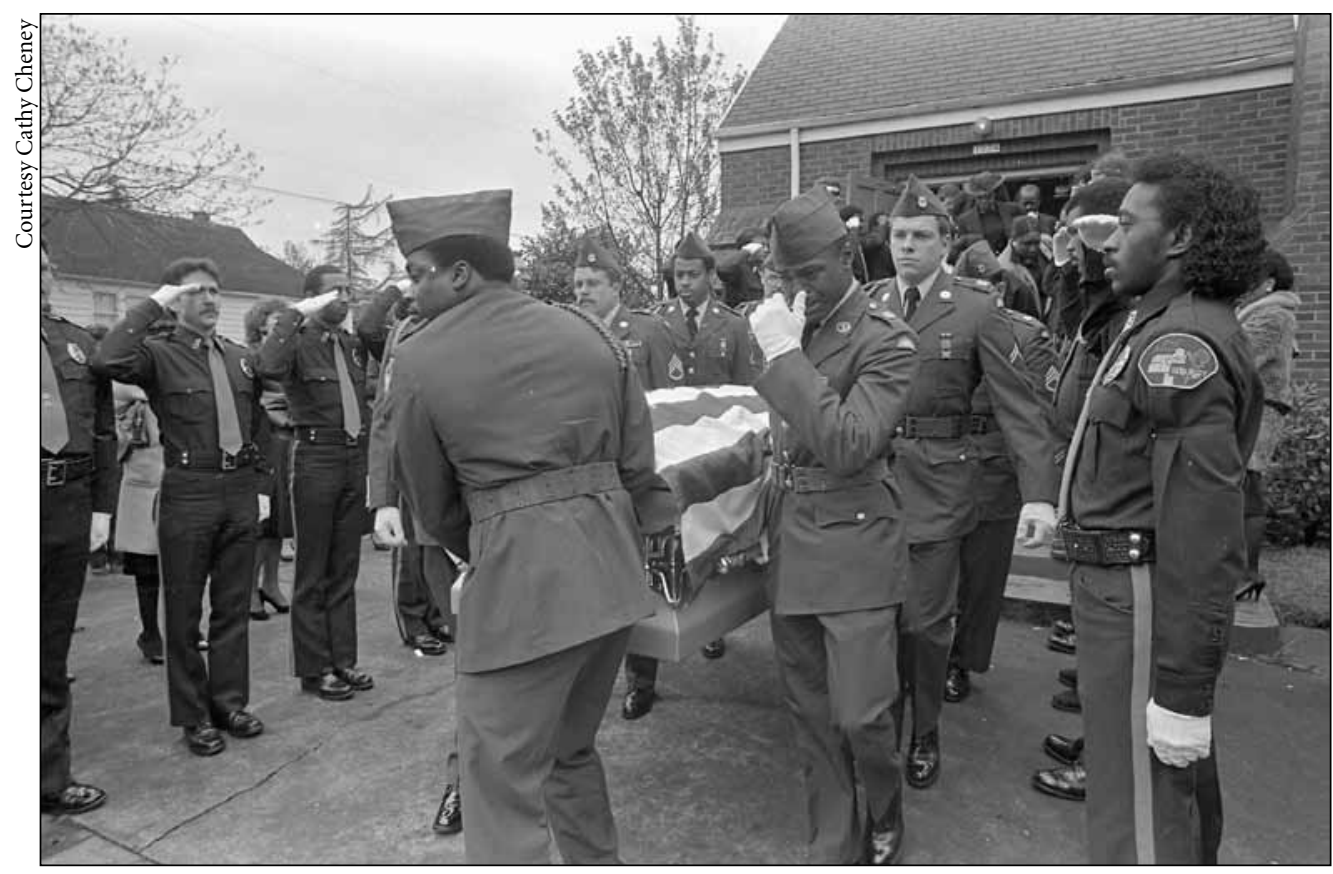

Mourners offer their respects at the funeral of Lloyd "Tony" Stephenson, a former U.S. Marine killed by Portland police in 1985.

institutionalized racism within the entire criminal justice system - and within society as a whole. According to Staples, the model gained "considerable credence" among black prisoners who, considering themselves "political prisoners," continued to resist colonial domination through prison protests. ${ }^{115}$ Many black urbanites interpreted their position in the American social structure as that of a colonized community during the era of oftenviolent resistance to the civil rights struggle for freedom and equality, and we should reconsider the model's utility.

The police have been critically important agents of an oppressive structure that resisted change in Portland and cities nationally. Complicit politicians, perhaps despite good intentions, repeatedly thwarted the attempts by Albina residents to reform the police. Those politicians would fit Albert Memmi's description of "de facto colonizers" in The Colonizer and the Colonized, because, "in the eyes of the colonized" they hold "a privileged economic position," belong to the "political system of oppression," or participate in "an effectively negative complex [that is, web of institutional structures] toward the colonized," perhaps unconsciously or perhaps not. Memmi observed: "The distinction between deed and intent has no great significance in the colonial 
situation." ${ }^{116}$ The colonial model helps us understand how the relationship among the police, local politicians, and the black community in Albina was characterized by external power and control as well as relative powerlessness among residents. African Americans struggled to gain some control over the police - the "agents" of the "status quo" relationship, in Staples's words yet were unable to gain meaningful participation in police oversight, which could have shifted power relations. Teasing out the implications of the "uneasy relationship" between black communities and "overwhelmingly white" police not only helps us understand that history in Portland but also adds to the national conversation about race, power, and justice.

\section{NOTES}

1. City Club of Portland, Report on Law Enforcement in the City of Portland, August 30, 1968, 139.

2. U.S. Riot Commission, Report of the National Advisory Commission on Civil Disorders (New York: Bantam Books, 1968), 1 [hereafter Kerner Report].

3. City Club of Portland, Report on Problems of Racial Justice in Portland, June 14, 1968, 5, 37, 39.

4. U.S. Census Office, Table H1, Occupancy, Utilization, and Financial Characteristics of Housing Units, Portland, Oregon-Wash SMSA (Washington, D.C.: Government Printing Office, 1970).

5. Richard White, "Faith, Hope, and Leverage: Attributes of Effective Faith-Based Community Organizations" (Ph.D. diss., Portland State University, 1996), 155-56.

6. William Sanderson, "Bitter, Frank, Articulate, Youth of Albina Speaks Up," Oregonian, August 6, 1967, 74 .

7. Kevin Mumford, "Harvesting the Crisis: The Newark Uprising, the Kerner Commission, and Writings on Riots," in African American Urban History since World War II, ed. Kenneth L. Kusmer and Joe W. Trotter (Chicago: University of Chicago Press, 2009), 214-15. See also Kerner Report, 56-69.

8. Thomas J. Sugrue, Sweet Land of Liberty: The Forgotten Struggle for Civil Rights in the North (New York: Random House, 2008), in particular chapter 10, "Long Hot
Summers," 313-55.

9. Michael B. Katz, The Undeserving Poor: From the War on Poverty to the War on Welfare (New York: Pantheon Books, 1989), chapter 2 , "Poverty and the Politics of Liberation," 36-78.

10. Robert Staples, "White Racism, Black Crime, and American Justice: An Application of the Colonial Model to Explain Crime and Race," Phylon 36 (1975): 14-22. Earlier scholarly literature characterizing race relations as internal colonialism includes Harold Cruse's essay, "Revolutionary Nationalism and the Afro-American," in Rebellion or Revolution? (New York: William Morrow, 1968), 97-125; Kenneth B. Clark's Dark Ghetto: Dilemmas of Social Power (New York: Harper \& Row, 1965); and Stokely Carmichael and Charles Hamilton's Black Power (New York: Random House, 1967).

11. See for example, Michelle Alexander, The New Jim Crow: Mass Incarceration in the Age of Colorblindness (New York: The New Press, 2010); and Ronald Weitzer and Steven A. Tuch, "Race and Police Misconduct," Social Problems 31:3 (August 2004): 305-25.

12. Marcy S. Sacks, "'To Show Who Was in Charge': Police Repression of New York City's Black Population at the Turn of the Twentieth Century," Journal of Urban History 31 (2005): 800 .

13. Kenneth Kusmer and Joe Trotter's recent anthology on black urban history in 
the post-World War II era, for example, has just one chapter that addresses the topic at length. Kenneth L. Kusmer and Joe W. Trotter, eds., African American Urban History since World War II (Chicago: University of Chicago Press, 2009), particularly chapter 10, Kevin Mumford, "Harvesting the Crisis: The Newark Uprising, the Kerner Commission, and Writings on Riots," 203-218.

14. Sacks, "To Show Who was in Charge," 799-800, 816.

15. City Club of Portland, Report on Problems of Racial Justice in Portland, 9.

16. Sugrue, Sweet Land of Liberty, 329-30, 357.

17. Stuart McElderry, "Building a West Coast Ghetto: African-American Housing in Portland, 1910-1960," The Pacific Northwest Quarterly 92:3 (Summer 2001): 137-48, 139.

18. Karen J. Gibson, "Bleeding Albina: A History of Community Disinvestment, 1940-2000," Transforming Anthropology 15:1 (April 2007): 3-25.

19. Ibid.

20. Annemette Sorensen and Karl Taeuber, "Indexes of Racial Residential Segregation for 109 cities in the United States, 1940 to 1970," Sociological Focus 8:2 (1975):125-42. The dissimilarity index measures the evenness of the population spread throughout the city. Hence, black residents, as 7 percent of the city's population, should have represented 7 percent of every neighborhood to spread evenly throughout the city. In 1970, Sorensen and Taeuber, using block-level census data, estimated that 86 percent of black Portlanders would have had to move in order to achieve evenness.

21. City of Portland, Portland Police Annual Report, 1963, in A2004-001, City of Portland Archives \& Records, Portland, Oregon [hereafter City of Portland Archives], especially interview between Chief Johnson and Oregonian reporter Robert Olmos.

22. "Jury Criticizes Officer in Shooting of Prisoner," Oregonian, June 13, 1964, 5.

23. Jack Berry, "Change Seen by Lawmen," Oregonian, June 13, 1964, 5. See also City Club of Portland, Report on Law Enforcement, 163.
24. Kenneth Robert Gervais, "The Portland Police Officer" (Ph.D. diss., Claremont Graduate School, 1968), 188.

25. Ben Jacklet, "Watcher Files Find New Home," Portland Tribune, January 13, 2004.

26. Gervais, "The Portland Police Officer," 140 .

27. Jim Fleming, "It's Like Making Bread," The Rap Sheet, June 1976, 2.

28. C.F. Trimble, Intelligence Report, June 10, 1965, A2004-005, City of Portland Archives; Frank K Springer, Inspection Report, 1966, in A2004-005, City of Portland Archives.

29. Stan Federman, "Negroes Break Windows, Set Fires, Police Move to Put Down Disturbance," Oregonian, July 31, 1967, 1.

30. Sanderson, "Bitter, Frank, Articulate, Youth of Albina Speaks Up."

31. City of Portland, Postal Inspector Interview with Colton Leroy Brown Jr, 1969, A2004-005, City of Portland Archives.

32. Ward Churchill and Jim VanDerWall, The COINTELPRO Papers: Documents from the FBI's Secret Wars Against Domestic Dissent (Boston: South End Press, 1990), 108.

33. Bill Keller, "Black Panther Clinics Target of FBI in 1970s," Oregonian, 1978, in A2004-005, City of Portland Archives.

34. U.S. Senate, Final Report of the Select Committee to Study Governmental Operations with Respect to Intelligence Activities, No. 94-755 (AKA Church Committee Report), Supplementary Detailed Staff Reports, Book III, “COINTELPRO: The FBI's Covert Action Programs against American Citizens," 94th Cong., 2d Sess., April 14, 1976 (Washington, D.C.: Government Printing Office, 1976), 3, available at http://www.intelligence.senate. gov/churchcommittee.html (accessed April 4, 2011). See also James Kirkpatrick Davis, Spying on America: The FBI's Domestic Counterintelligence Program (New York: Praeger, 1992), 97-127.

35. Dennis West, "A Case Study of the Planning Process in the Portland, Oregon, Model Cities Program" (Ph.D. diss., Claremont Graduate School, 1969).

36. Robert Olmos, "Community Relations Unit Fights Bombing," Oregonian, May 9, 1971, 98 . 
37. Andrew Mershon, "Former Black Beret Leader Takes OEO Treasurer Post," Oregonian, March 3, 1971, 35.

38. Robert Olmos, "Model Cities Aide Threatens to Blow Whistle on Police Shift," Oregonian, March 31, 1971.

39. Intelligence Reports, 1971, A2004005, City of Portland Archives. "Anderson Resigns, Frees City Anti-Poverty Money," Oregonian, April 1, 1971. "Intelligence Report by LA Ferreira on PCR detail," April 6, 1971, in Black Community Survival Committee papers, 2/2, 2004-005, City of Portland Archives. Daily Activity Report, April 8, 1971, in A2004-005, City of Portland Archives.

40. "Community Police Unit Hit in Report," 1971, in A2004-005, City of Portland Archives.

41. Jim Fleming, "Period Critical for Minority Areas," The Rap Sheet, May 1979, 12. 42. "Fourteen Blacks File Suit on Rights, 38 Policemen, City Officials Cited in Action," Oregonian, September 18, 1969, 1.

43. Julie Tripp, "The Guardians: Effect of 1971 Decree Largely Negligible," Oregonian, June $7,1981,50$.

44. Ibid.

45. Judd Smith, "Mayor Outlines Future of Police Bureau," Oregonian, February 25, 1973, 69.

46. "Most Complaints against Police Unfounded," The Rap Sheet, February 1974, 1.

47. Rachel James to Mayor Goldschmidt, 1974, in Constituent Complaints - Police Excessive Force and Racial Discrimination, A2000-017, City of Portland Archives.

48. "Inquest Jury Decides Justifiable Homicide," The Rap Sheet, May 1975, 5.

49. "Probe Due Portland Shootings," Oregonian, April 25, 1975, 1.

50. "Misinformation Flabbergasting," The Rap Sheet, June, 1975, 1.

51. "Lezak Rules out Jury Probe of Shooting Deaths," Oregonian, September 19, 1975, 1.

52. Jim Harvey, "The Parable of the Tick and the Cow," The Rap Sheet, December, 1975, 5 .

53. Jim Fleming, "Bureau Drags its Feet on Minority Hiring," The Rap Sheet, May 1974, 1.
54. Bill Rhodes to Charles Jordan (memo), 1980, in Portland Police Affirmative Action, A2000-010, City of Portland Archives.

55. Jim Fleming, "Billboards Produce Mixed Reaction," The Rap Sheet, August 1977,5 .

56. Ibid.

57. Joyce Bales, "Once More, with Feeling," The Rap Sheet, June 1979, 15.

58. Jim Fleming, "Portland Police Association Favors Improved Minority Recruiting," The Rap Sheet, June 1980, 1.

59. Bill Rhodes to Charles Jordan (memo), 1980, in Portland Police Affirmative Action, A2000-010, City of Portland Archives.

6o. Jim Fleming, "Bureau Drags its Feet on Minority Hiring," The Rap Sheet, May 1974, 1.

61. Ibid. See also Jim Fleming, "Billboards Produce Mixed Reaction," The Rap Sheet, August 1977, 5.

62. Stan Peters, "Peters Asks Jordan to Set Right Comments Hurting our Integrity," The Rap Sheet, September 1980, 1.

63. "Police in the 1980s," 1983, in Commissioner (Archival) Jordan, Charles R. Collected Reports and Studies, A200o-o, City of Portland Archives.

64. Committee to Support the Black United Front, "The Two Faces of Portland: Racism in the Most Livable City," 1982; "Black Convention Urges Unity and Dedication," 1983, Grassroots News NW, clipping in Black United Front (National), A 2004-005, City of Portland Archives.

65. Jerry Blair, Brad Conklin, and Larry Neville, "It's Called Blue Power, Police Unions Become Politically Active," The Rap Sheet, February 1978, 10.

66. Susan Hauser, Pickets, Pistols, and Politics: A History of the Portland Police Association (Portland, Ore.: Portland Police Association, 1996); Sebastian Coco, "We're the Oldest," The Rap Sheet, October 1974, 18.

67. Stan Peters, "Peters Rebuts Critics of PPA Political Action," The Rap Sheet, March 1976, 1, 10 .

68. Stan Peters, "Blue Liberation Movement Results Are Satisfying," The Rap Sheet, November 1979, 1. 
69. Susan Falk, "Union Assisting Officers in Filing Assault Cases," The Rap Sheet, January 1982,3 .

70. "Right to Sue Emphasized," The Rap Sheet, August 1982, 10. "Officer Asks for Retraction," The Rap Sheet, July 1981, 2.

71. Walli Schneider, "Blacks Defend Filing Complaint with U.N. Agency," Oregon Journal, January 28, 1981.

72. "Police in the 1980s," 1983, in Commissioner (Archival) Jordan, Charles R. Collected Reports and Studies, A200o-o, City of Portland Archives.

73. Linda Williams, "Prejudice Denied: Police Union Defends Arrest Ratio," Oregonian, January 31, 1981, 8.

74. Schneider, "Blacks Defend Filing Complaint with U.N. Agency." A review of Skanner and Portland Observer articles from July 1980 through February 1982 revealed no mention of a U.N. investigation.

75. Commissioner Jordan Subject Files, Police Civil Services, 1978-1983, A200o-010, City of Portland Archives.

76. David Whitney, "Judge Invalidates Minority Hiring Rules," Oregonian, August 9, 1980, 1 .

77. A Report of Current Citizen Police Review Board (PIIAC), 2000, A2004-020, City of Portland Archives. Black United Front, 1/3, A2004-005, City of Portland Archives.

78. Charles Steers, "Blacks Claim Possum Action Insult by Police," Oregon Journal, March 19, 1981.

79. Benny Evangelista, "Police Tale Questioned by Owner," Oregonian, March 16, 1981, 21.

80. Pickett Nelson, "150 Rally to Protest Possum Incident," Oregon Journal, March 26, 1981; Pickett, "Two Officers Deny Racial Harassment," Oregon Journal, March 23, 1981.

81. Susan Falk, "Vote Indicates Displeasure," The Rap Sheet, May 1981, 12.

82. Jeff Barker, "A True Show of Support for Officers," The Rap Sheet, May 1981, 1.

83. Hauser, Pickets.

84. Jeff Barker, "No Baker, Jordan Support," The Rap Sheet, June 1981, 1.

85. Diane Carmon, "Ivancie Police Ac- tions Insult to Black Community," Oregon Journal, June 3, 1981.;Linda Williams, "Jordan Sees Totally Different Bureau Under Ivancie," Oregonian, June 2, 1981.; Williams, "Critics to Give Police Chief Chance," Oregonian, June 3, 1981. For a detailed discussion of the Black Panthers and the Portland police, see Jules Boykoff and Martha Gies, "'We Were Going to Defend Ourselves': The Portland Chapter of the Black Panther Party and the Local Media," Oregon Historical Quarterly 111:3 (Fall 2010): 278-311.

86. Alan Ota, "Black United Front Calls Protest March," Oregonian, August 14, 1981, 23; Alan Ota, "Arbiter Ruling Feared," Oregonian, August 18, 1981, 61.

87. Intelligence Report, August 20, 1981, in Black United Front, 1/3, A2004-005, City of Portland Archives.

88. A Report of Current Citizen Police Review Board (PIIAC), 2000, A2004-020, City of Portland Archives.

89. "PPA Voices Strong Protest to Review Board Proposal," The Rap Sheet, April 1982, 1; Jeff Barker, "Vote for Board by City Council Brings PPA Drive," The Rap Sheet, May 1982, 1.

90. Blacks in Oregon, 1978, A2004-005, City of Portland Archives; Jeff Barker, "Our Efforts Fail as Measure 51 Narrowly Passes," The Rap Sheet, December 1982, 1.

91. Ibid.; Jeff Barker, "View the Reviewers with Jaundiced Eye," The Rap Sheet, July 1985, p. 11.

92. Phil Manzano, "Distrust, Frustration Mark Police Monitoring Group," Oregonian, February 12, 1987, 59.

93. "Public Safety Memo," October 12, 1987, in Public Safety 87/88, 17-2-43, 3/20, 8/6, 04-03-07, City of Portland Archives.

94. Tom Hallman, "Portlander Dies after Police Use 'Sleeper Hold," Oregonian, April 21, 1985"; Holly Danks and Paul Manley, "Harsh Discipline Asked in T-Shirt Incident; Second Officer Cited," Oregonian, April 30, $1985,23$.

95. Ibid.

96. Jeff Barker, "Portland Police Association Continues to Stand behind its Members 100\%," The Rap Sheet, June 1985, 1. 
97. "Officers Upheld," The Rap Sheet, November 1985, 1.

98. Richard Read, "T-Shirt Pair File Claim against the City," Oregonian, November 2, 1985, 29; Gordon Oliver, "Judge Recommends Rejection of T-Shirt Case Claims," Oregonian, October 20, 1988, C-4.

99. Ken Hamburg, "Inquest Jury Sees Stevenson Death as Homicide," Oregonian, May 12, 1985, 1.

100. "Fair Housing Strategy Plan for the City of Portland," 1986, in Commissioner (Archival) Lindberg, Mike, Subject Files, A2000-001, City of Portland Archives; Gibson, "Bleeding Albina." 101. Frank Cox, "The Portland Model Cities Community Development Program," June 1, 1970, 9. 102. Judson Randall,

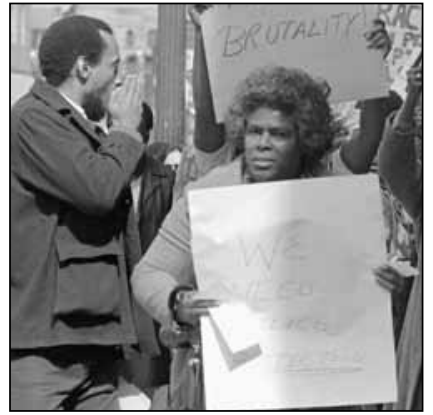

Courtesy Cathy Cheney
Killed by Police Adds Allegations," Oregonian, March 18, 2011, 1. Maxine Bernstein, "Portland Will Fight Cop's Return," Oregonian, October 5, 2012, 1.

110. Bernstein, "Family of Man Killed by Police."

111. "Portland Police Shootings and Deaths in Custody," Portland Copwatch, available at http://www.portlandcopwatch. org/listofshootings.html (accessed November 15, 2011).

112. Helen Jung, "Portland Police Seek Money to Help Diversify the Ranks as Officers Retire," Oregon Live, March 30, 2010, available online at http://www. oregonlive.com/portland/ index.ssf/2010/03/portland_police_seek_money_to.html (accessed on November 15, 2011); Karen J. Gibson, "All New and "Arson Held Primary Cause of Dwindling Shiny? Social Inequality in Portland's Albina Economy of Albina," Oregonian, October $18,1970,38$.

103. "Black Convention Urges Unity and Dedication," 1983, Grassroots News NW, clipping in Black United Front (National), A 2004-005, City of Portland Archives.

104. See Black United Front (National,) A2004-005, City of Portland Archives. "Black United Front Asks President to Cancel Debate in 'Racist' Portland, OR,' Oregon Journal, clipping, September 5, 1980, in Black United Front, 1/3, A2004-005, 6/1, City of Portland Archives.

105. Tamari Kitossa, "Criminology and Colonialism: Counter Colonial Criminology and the Canadian Context," Journal of Pan African Studies 4:10 (January 2012): 211. 106. "Filmmaker's interview transcript," Imagining Home, DVD, directed by Sue Arbuthnot and Richard Wilhem (Portland, Ore.: Hare in the Gate Productions, 2009).

107. Jim Fleming, "Police Morale," The Rap Sheet, October 1977, 5.

108. Jeff Barker, "No Baker, Jordan Support," The Rap Sheet, June 1981, 1.

109. Maxine Bernstein, "Family of Man
District" (Conference Presentation, Urban Affairs Association Annual Meeting, Pitttsburgh, Penn., 2012)

113. Dr. Leroy Haynes, Chair, Albina Ministerial Association Coalition for Justice and Police Reform, and Senior Pastor, Allen Temple, Portland, interview with authors, October 31, 2012. The interracial Coalition for Justice and Police Reform is comprised of two dozen organizations, including the Albina Ministerial Alliance, Portland Copwatch, the ACLU, Lawyers Guild, the Latino Network, and the Portland Urban League.

114. Robert Blauner, "Internal Colonialism and Ghetto Revolt," Social Problems 16:4 (1969): 393-408, 115; Staples, "White Racism, Black Crime and American Justice," 14.

115. Staples, "White Racism, Black Crime, and American Justice," 14

116. Albert Memmi, The Colonizer and the Colonized (Boston: Beacon, 1967), cited in Blauner, "Internal Colonialism and Ghetto Revolt," 401-402. Memmi's book is based on ized between the French and the colonized Arab majority in North Africa. his experience as a Tunisian Jew, marginal- 